\title{
Taxonomic novelties of hysteriform Dothideomycetes
}

\author{
Jayasiri SC ${ }^{1,2}$, Hyde KD ${ }^{1,3}$, Jones EBG ${ }^{4}$, Peršoh D ${ }^{5}$, Camporesi E6, Kang JC \\ ${ }^{1}$ Center of Excellence in Fungal Research, Mae Fah Luang University, Chiang Rai 57100, Thailand \\ ${ }^{2}$ Engineering Research Center of Southwest Bio-Pharmaceutical Resources, Ministry of Education, Guizhou \\ University, Guiyang 550025, Guizhou Province, China \\ ${ }^{3}$ World Agro forestry Centre East and Central Asia Office, 132 Lanhei Road, Kunming 650201, China \\ ${ }^{4}$ Nantgaredig, 33B St. Edwards Road, Southsea, Hants. PO5 3DH, UK \\ ${ }^{5}$ Ruhr-University Bochum, AG Geobotany, building ND 03/170, Universitätsstraße 150, 44801 Bochum, Germany \\ ${ }^{6}$ A.M.B. GruppoMicologicoForlivese "Antonio Cicognani", Via Roma 18, Forlì, Italy; A.M.B. CircoloMicologico \\ "Giovanni Carini", C.P. 314, Brescia, Italy; Società per gli Studi Naturalistici della Romagna, C.P. 144, \\ Bagnacavallo (RA), Italy
}

Jayasiri SC, Hyde KD, Jones EBG, Peršoh D, Camporesi E, Kang JC 2018 - Taxonomic novelties of hysteriform Dothideomycetes. Mycosphere 9(4), 803-837, Doi10.5943/mycosphere/9/4/8

\begin{abstract}
Hysteriaceous ascomycetes are an interesting and important group of fungi belonging to a small number of families and orders in the class Dothideomycetes. They can be saprobes, endophytes and/or ectomycorrhizal. Hysteriaceous fungi mainly occur on twigs or bark of various woody and herbaceous plants in terrestrial and aquatic environments worldwide. They have evolved convergently at least five times, and further studies are needed to resolve the taxonomic placement of new and previously described taxa. In this study, we introduce a new order, Gloniales, to accommodate Glonium, a new family, Acrogenosporaceae, to accommodate Acrogenospora, five new species (Hysterium doimaeensis, H. thailandica, Hysterobrevium hakeae, Hy. rosae and Mytilinidion didymospora) and a new combination (Purpurepithecium minus). New records are provided with descriptions and illustrations are given for Gloniopsis subrugosa, Hysterium angustatum and Hysterographium fraxi. The findings are supported by morphological and phylogenetic analyses of LSU SSU, RPB2 and TEF1 sequence data. In addition, amino acid sequences of $R P B 2$ were phylogenetically analyzed.
\end{abstract}

Keywords - Acrogenosporaceae - Gloniales - hysteriaceous - Hysterium - Hysterobrevium Hysterographium

\section{Introduction}

We are studying the diversity of fungi on various hosts in Thailand and have investigated the phylogenetic relationships among taxa of Dothideomycetes (Ariyawansa et al. 2015, Liu et al. 2015, Boonmee et al. 2016, Doilom et al. 2017). The hysteriform taxa in Dothideomycetes are the focus of the present study. In our previous studies of this group, we have introduced a new family, two new genera, seven new species, as well as three new records from different hosts and localities (Hyde et al. 2013, Liu et al. 2015, Hyde et al. 2016, Jayasiri et al. 2016, 2017, Li et al. 2016, Thambugala et al. 2016, Doilom et al. 2017). This manuscript provides a further contribution to the hysteriform Dothideomycetes with updated backbone trees. 
In general different terminologies are used for this group of fungi based on their ascomatal morphology; there are called "hysteriaceous", "hysteriform" and "hysterothecioid" ascomycetes (Boehm et al. 2009a, b). Hysteriaceous ascomycetes incorporate those fungi having lirelliform ascomata, generally called hysterothecia (Clements \& Shear 1931). They are found worldwide as saprobes and occur on twigs or bark of various woody and herbaceous plants in terrestrial and aquatic environments (Boehm et al. 2009a, b, Hyde et al.2013, Liu et al. 2015, Hyde et al. 2016, Li et al. 2016, Doilom et al. 2017). However, some taxa may also be endophytes (Xu et al. 2015), or ectomycorrhizae (Spatafora et al. 2012).

There have been numerous studies on hysteriform Dothideomycetes and a large number of epithets in this group have been introduced, mostly in the $20^{\text {th }}$ century. During this time various researchers tried to identify these fungi by ascomatal macroscopic features, and host occurrence (Boehm et al. 2009a, b). Zogg (1962) emphasized the colour, number of septa and size of ascospores as the main criteria for separating species and genera. At the ordinal level, the Hysteriaceae have been classified in Pseudosphaeriales (Gäumann 1949), Dothiorales (Müller \& von Arx 1950), Dothideales (von Arx \& Müller 1975), Pleosporales (Barr 1987) or in its own order, Hysteriales (Luttrell 1955, Kirk et al. 2001, 2008). Hysteriaceous fungi producing conchate or dolabrate, thin-walled, laterally compressed ascomata with an evaginated slit, were segregated from Hysteriaceae and placed in Mytilinidiaceae, under Melanommatales (Barr 1990a), because of their trabeculate pseudoparaphyses. This character, which occurs in most hysteriform taxa, was later shown to have evolved in many groups of Dothideomycetes (Liew et al. 2001). The family Mytilinidiaceae has also been placed in Pleosporales (Kirk et al. 2008) or Mytilinidiales (Boehm et al. 2009b, Lumbsch \& Huhndorf 2010). Boehm et al. (2009b) were the first to study the group at the molecular level and produce a phylogenetic outline. Phylogenetic studies based on molecular data have shown that hysteriaceous fungi do not form a monophyletic group (Boehm et al. 2009a, b, Mugambi \& Huhndorf 2009).

Currently, hysteriform ascomycetes are known from four orders of ascomata, namely Hysteriales, Mytilinidiales, Pleosporales, and Stigmatodiscales (Boehm et al. 2009a, b, Voglmayr et al. 2017). Hysteriales and Mytilinidiales exclusively only contain hysterothecioid taxa. Anteagloniaceae is a family with hysterothecia found in the order Pleosporales. Stigmatodiscus pruni is a hysteriform species in the order Stigmatodiscales. Boehm et al. (2009b) placed Gloniaceae in Pleosporomycetidae families, incertae sedis, because of inadequate sequence evidence to raise the family to ordinal status. Jayasiri et al. (2017), however, introduced a new genus, thus increasing the numbers of taxa for this group supported by molecular data.

Currently two hysteriform Dothideomycetes genera are placed in Pleosporomycetidae genera incertae sedis: Farlowiella (asexual morph: Acrogenospora) and Hysterographium (Goh et al. 1998, Boehm et al. 2009a). Acrogenospora is protected over Farlowiella, based on the wider use and fewer name changes required, rather than following the principle of priority (Rossman et al. 2015). In this study we revisit this group with novelties based on morphology and phylogenetic data. We introduce a new order, a new family, five new species, a new combination and document three new records.

\section{Material and Methods}

\section{Sample collection and specimen examination}

Fresh materials were received and collected from Australia, Italy, Russia and Thailand in 2012, 2015 and 2016. Specimens were observed using a Motic SMZ 168 series microscope. Hand sections of fruiting structures were mounted in water for microscopic studies and photomicrography. The fungi were examined with a Nikon ECLIPSE 80i compound microscope and photographed with a Canon 450D digital camera connected to the microscope. Measurements were made with the Tarosoft (R) Image Frame Work program and images used for the figures were processed with Adobe Photoshop CS6 Extended version 10.0 software (Adobe Systems, USA). 
Isolations were obtained from single ascospores, following a modified method of Chomnunti et al. (2014).

Voucher specimens are deposited in the herbarium of Mae Fah Luang University (Herb. MFLU) and New Zealand Fungal \& Plant Disease Collection (PDD) or Herbarium of Cryptogams, Kunming Institute of Botany Academia Sinica (HKAS). Living cultures are deposited in the culture collection of Mae Fah Luang University (MFLUCC), Thailand with a duplicate set at the Culture Collection of Kunming Institute of Botany (KUMCC) or BIOTEC Culture Collection (BCC), Bangkok, Thailand. Faces of fungi and IF numbers were registered as in Jayasiri et al. (2015), Index Fungorum (2018).

\section{DNA extraction, PCR amplification and sequencing}

Genomic DNA was extracted from the mycelium after growing for 14 days on MEA at $18^{\circ} \mathrm{C}$ using the Biospin Fungus Genomic DNA Extraction Kit (BioFlux®) and following the manufacturer's protocol (Hangzhou, P.R. China). DNA was extracted directly from ascomata using a DNA extraction kit (E.Z.N.A. ${ }^{\circledR}$ Forensic DNA kit, D3591- 01, Omega Bio-Tek) following the manufacturer's instructions. DNA was amplified by Polymerase Chain Reaction (PCR). The partial large subunit nuclear rDNA (LSU) was amplified with primer pairs LROR and LR5 (Vilgalys \& Hester 1990). The small subunit nuclear rDNA (SSU) was amplified with primer pairs NS1 and NS4 (White et al. 1990). The RNA polymerase II second largest subunit (RPB2) gene was amplified with primers fRPB2 and fRPB2-7cR (Liu et al. 1999, Sung et al. 2007). The translation elongation factor 1-alpha gene (TEF1) was amplified by using primers EF1-983F and EF1-2218R (Rehner 2001).

The PCR was carried out in a $50 \mu \mathrm{l}$ reaction volume containing $2 \mu 1$ DNA, $25 \mu \mathrm{l}$ PCR mix, 19 $\mu 1$ distilled water and $2 \mu \mathrm{l}$ of each primer. Amplifications of LSU, SSU, RPB2 and TEF1 were performed under standard conditions (White et al. 1990). Purification and sequencing of PCR products were carried at Shanghai Sangon Biological Engineering Technology and Services Co. (China).

\section{Sequence alignment and phylogenetic analyses}

Sequences generated from the LSU, SSU, RPB2 and TEF1 gene regions were carefully verified using blast result in GenBank, before further analyses. All introns and exons were aligned individually. Ambiguously aligned regions with many leading or trailing gaps were excluded from the alignments prior to phylogenetic reconstructions. Multiple sequence alignments were produced with MAFFT v. 6.864b (http://mafft.cbrc.jp/alignment/server/index.html) and further improved manually where necessary. The final phylogenetic tree used to infer the taxonomic placement of our new taxon was generated based on DNA sequence analyses of a concatenated dataset of LSU, SSU, RPB2 and TEF1 gene sequences. A maximum likelihood analysis was performed at CIPRES using RAxML v.7.2.8 as part of the "RAxMLHPC2 on TG" tool (Stamatakis et al. 2008). The general time reversible model (GTR) using proportion of invariable sites was applied with a discrete gamma distribution and four rate classes. The sequences of novel species and other newly generated sequences were deposited in GenBank (Appendix 1) and the final matrices used for phylogenetic analyses were saved in TreeBASE (ID 22543).

The most suitable model of evolution was estimated using MrModeltest 2.2 (Nylander 2004). Posterior probabilities (PP) (Rannala \& Yang 1996, Zhaxybayeva \& Gogarten 2002) were determined by Markov Chain Monte Carlo sampling (MCMC) in MrBayes v. 3.0b4 (Huelsenbeck \& Ronquist 2001). Six simultaneous Markov chains were run for 10,000,000 generations and trees were sampled every 100th generation. The first 100,000 trees, representing the burn in phase of the analyses, were discarded, while the remaining trees (80000) were used for calculating posterior probabilities in the majority rule consensus tree. Bayesian Posterior Probabilities (BYPP) equal or greater than 0.90 are indicated on the resulting tree topology (Fig. 1). Phylogenetic trees were drawn using FigTree v. 1.4 (Rambaut \& Drummond 2008). 


\section{Amino acid sequence analysis}

The RPB2 gene sequences were translated into protein sequences using ARB (Ludwig et al. 2004, Perera et al. 2018, Thambugala et al. 2018). The phylogenetic analysis was conducted with RAxML and the Blosum62 amino acid substitution model. Only amino acids 291 to 472 according to ACJ60608 (Mytilinidion andinense) were used for the analysis.

\section{Results}

\section{Phylogenetic analyses of DNA sequences}

Three hundred and one strains were included in the combined LSU, SSU, RPB2 and TEF1 gene analyses with Schismatomma decolorans (AFTOL-ID 307) as the outgroup taxon. Tree topology of the Bayesian analysis was compatible with the ML tree and was not significantly different (data not shown). The best scoring RAxML tree with a final likelihood value of 117967.323834 is shown in Fig. 1. Five clades are represented in the figure: Clade A represents the main family of hysteriform Dothideomycetes (Hysteriaceae), Clade B is the new order Gloniales, Clade C Mytilinidiales, Clade D Hysterographium sp. and Clade E represents a new family Acrogenosporaceae. Our isolates and new findings are described in these groups based on morphology and phylogenetical data.

The nine strains included in the combined LSU, SSU, RPB2 and TEF1 gene analyses for the new family Acrogenosporaceae with Hysterographium fraxini (CBS 242.32 and CBS 109.43) as the outgroup taxon. The best scoring RAxML tree with a final likelihood value of -8652.600999 is shown in Fig. 2. Original names are used in here for the better interpretation of this group.

\section{Phylogenetic analyses of amino acid sequences}

Amino acid sequence analysis of $R P B 2$ was conducted for the same data set as used for multigene phylogenetic analyses. Except for hysteriform Dothideomycetes species others were collapsed to order level in the resulting tree (Fig. 3). Based on this tree (Fig. 3) we have identified the main orders of the class Dothideomycetes. Among the hysteriform group's new family Acrogenosporaceae (Part E), Mytilinidiales (Part C) and the order Stigmatodiscales (Part F) are monophyletic and have the same topology as phylogenetic analyses of DNA sequences. However, Gloniales (Part D), Hysteriales (Part A) and Pleosporales (part B) are paraphyletic in here and a few Pleosporales species are polyphyletic.

\section{Phylogenetic analyses - ordinal level}

Minutisphaerales Raja, Oberlies, Shearer \& A.N. Mill., Mycologia 107: 854 (2015)

Notes - Based on phylogenetic analyses of combined SSU and LSU data, Raja et al. (2015) introduced new order Minutisphaerales within the Dothideomycetes. The Minutisphaera spp. clade is a monophyletic, strongly supported clade of freshwater Dothideomycetes (Raja et al. 2013, 2015). In the present study further confirmed placement of order Minutisphaerales with the Minutisphaeraceae and a new family Acrogenosporaceae.

Minutisphaeraceae is characterized by erumpent to superficial, pseudothecioid or apothecioid ascomata with ostioles, a thin-walled peridium and clavate, fusiform to ellipsoidal, multi-guttulate ascospores surrounded by a gelatinous sheath.

All currently described Minutisphaera spp. (M. fimbriatispora, M. japonica, M. aspera and M. parafimbriatispora) have been isolated from submerged wood in freshwater habitats (Ferrer et al. 2011, Raja et al. 2013, 2015). Therefore, this order comprises freshwater saprobic fungi. This ecological group plays an important role in nutrient cycling and organic matter decomposition in freshwater habitats (Simonis et al. 2008, Shearer et al. 2009, Hyde et al. 2016). 
Hysterobrevium mori CBS 123563 Hysterobrevium mori CBS 123335 Hysterobrevium mori CBS 123336

100/1.0 Hysterobrevium mori MFLUCC 14-0520

Hysterobrevium mori CBS 123564 100/1.0 Hysterobrevium mori SMH 5273

Hysterobrevium rosaeium MFUCC 14-0551

Hysterobrevium rosaeium MFUCC 14-0552

Hysterobrevium smilacis SMH5280

Hysterobrevium smilacis CBS 200.34

96/1.0 Hysterobrevium smilacis CBS 114601

Hysterobrevium moriSMH

93/- - Hysterobrevium smilacis GKM426N

75/-- Hysterobrevium smilacis CMW 18053

94/1. Hysterobrevium constrictum SMH5211.1

Hysterobrevium hakeae MFLU 16-2987

77/-- Psiloglonium sasicola MFLUCC 10-0565

73/-- Psiloglonium colihuae MFLUCC 11-0178

Lsiloglonium multiseptatum MFLUCC 11-0164

96/1.0 Psiloglonium araucanum CBS 112412

Psiloglonium araucanum CMW 18760

Psiloglonium araucanum CMW 17941

100/1.0. Psiloglonium simulans ANM1557

Psiloglonium simulans CBS 20634

70/-- Psiloglonium clavisporum CBS 123338

70/- Psiloglonium clavisporum CBS 123341

9/1.0 Psiloglonium clavisporum CBS 123341

Psiloglonium clavisporum GKM L172A

Psiloglonium clavisporum GKM344A

100 Psiloglonium macrosporum MFLUCC 16-0603

Psiloglonium macrosporum MFLUCC 13-0448

79/--

99/1.0- Hysterium angustatum MFLUCC 16-0623

Hysterium angustatum CMW 20409

Hysterium angustatum GKM5211

- Hysterium angustatum GKM243a

Hysterium angustatum SMH5216

Hysterium angustatum CBS 236.34

Hysterium anqustatum CBS 123334

$76 / 0.95$

1.0 Hysterium pulicare CBS 123377

79/-- Hysterium pulicare ANM85

Hysterium vermiforme GKM1234

A

Ostreichnion curtisii CBS 198.34

Hysterium doimaeensis MFLUCC 16-0338

Hysteriales

98/1.0 - Hysterium thailandicum MFLUCC 16-0338

00/1.0 Hysterium centramurum MFLUCC 12-0808

sterium barrianum ANM1495

Hysterium barrianum ANM1442

Hysterographium flexuosum GKM1262c

Ostreichnion sassafras CBS 322.34

Rhytidhysteron neorufulum EBO381

Rhytidhysteron neorufulum MFLUCC 13-0216

Rhytidhysteron neorufulum MFLUCC 13-0221

Rhytidhysteron neorufulum CBS 306.38

Rhytidhysteron neorufulum MFLUCC 12-0528

Rhytidhysteron neorufulum MFLUCC 12-0569

95/1.0 Rhytidhysteron neorufulum MFLUCC 12-0567

Rhytidhysteron neorufulum MFLUCC 12-0011

Rhytidhysteron tectonae GKM361A

Rhytidhysteron tectonae MFLUCC 13-0710

Rhytidhysteron sp. MFLUCC 12-0529

Rhytidhysteron rufulum $\mathrm{EB} 0383$

$85 /--$ Rhytidhysteron rufulum EB 0384

100/1.0 - Rhytidhysteron rufulum EB 0382

Rhytidhysteron rufulum MFLUCC 140577

Rhytidhysteron rufulum MFLUCC 120013

Rhytidhysteron thailandicum MFLUCC 120530

99/1.0 $\quad \begin{array}{r}\text { Rhytidhysteron thailandicum } \\ \text { Rhytidhysteron hysterinum EB } 0351\end{array}$

76/ Gloniopsis subrugosa MFI CC 14-1179

- Gloniopsis subrugosa SMH 557

Gloniopsis subrugosa GKM1214

Gloniopsis arciformis GKM L166A

100/1. G Gloniopsis praelonga CMW 19983

100/1.0 Gloniopsis praelonga CBS 112415

Gloniopsis praelonga CBS 123337

Gloniopsis subrugosa CBS 123346

Gloniopsis kenyensis GKM1010

- Gloniopsis calami MFLUCC 15-0739

92.-- Gloniopsis sp. MFLUCC140581

91/-- Oedohysterium insidens ANM1443

93/-- Oedohysterium insidens CBS 2383

$76 /-100 / 1.0-$ Oedohysterium sinense EB 0339

Oedohysterium sinense CBS 123345

Graphyllium caracolinensis HUEFS 42838

Hysterobrevium mori GKM 1013 


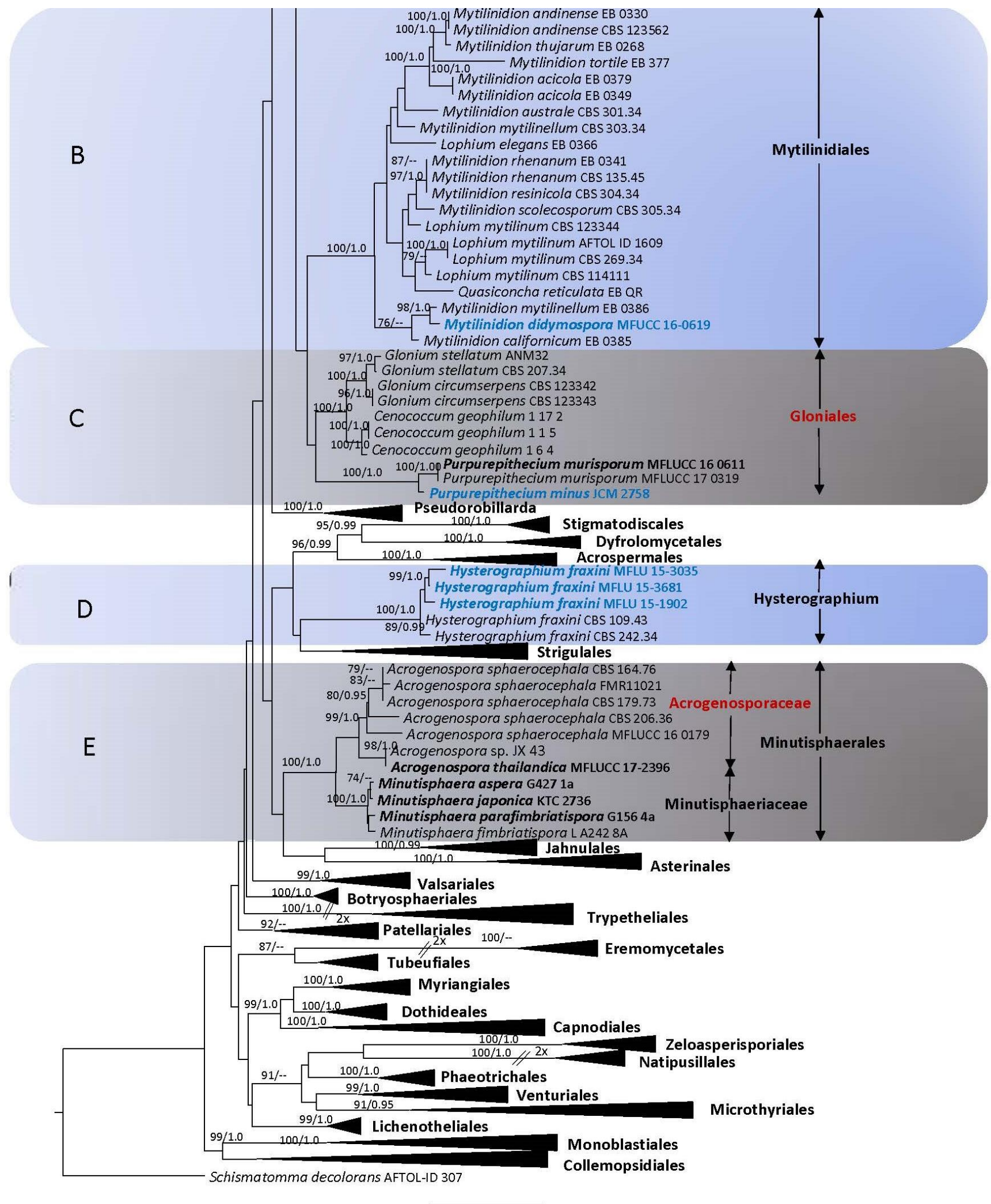

Figure 1 - Simplified phylogram showing the best RAxML maximum likelihood tree obtained from the combined multigene (LSU, SSU, RPB2 and TEF1) matrix of 301 taxa including major orders in Dothideomycetes, Schismatomma decolorans (AFTOL-ID 307) is selected as the outgroup taxon. Except for Gloniales, Hysteriales, Hysterographium spp., Minutisphaerales and Mytilinidiales, other lineages were collapsed to ordinal level. ML bootstrap support equal or greater than $70 \%$ and Bayesian posterior probabilities equal or greater than 0.95 are given near to each branch. Newly generated strains are in blue and type species are in bold. 
Acrogenosporaceae Jayasiri \& K.D. Hyde, fam. nov.

Index Fungorum number: IF554451; Facesoffungi number: FoF04575

Saprobic on bark and wood. Sexual morph: Hysterothecia laterally compressed, thick-walled, with a prominent sunken slit, solitary to gregarious, erect and elevated, presenting an almost stipitate appearance. Ascospores 1-celled, pedicellate, slightly laterally compressed amerosporous, hyaline or moderately pigmented. Asexual morph: Described in the genus Acrogenospora (Goh et al. 1998).

Type - Acrogenospora sphaerocephala (Berk. \& Broome) M.B Ellis, Dematiaceous Hyphomycetes: 114 (1971)

=Monotospora sphaerocephala Berk. \& Broome, Annals and Magazine of Natural History 3: 361, t. 9:5 (1859)

Notes - Using the concept of "one name one fungus" Rossman et al. (2015) suggested to keep Farlowiella as a synonym of Acrogenospora. Acrogenospora was favored as it would contribute to nomenclatural stability (Rossman et al. 2015). The generic name Acrogenospora, typified by $A$. sphaerocephala, includes two of the eleven species that have sexual morphs placed in Farlowiella typified by $F$. repanda (also considered to be $F$. carmichaeliana) (Rossman et al. 2015). Hyde et al. (2018) re-examined and introduced molecular data for the type species (Acrogenospora sphaerocephala) and another new Acrogenospora species. In our study, we used seven isolates related to this group, but many strains do not have any associated morphological descriptions (CBS 164.76, FMR 11021 and JX 43). A. sphaerocephala (MFLUCC 16-0179) clusters with Farlowiella carmichaeliana (CBS 206.36, CBS 179.73, JX FMR 11021) and A. sphaerocephala (CBS 164.76) with high statistical support in both DNA and protein trees. Therefore, this study supports Farlowiella as a synonym of Acrogenospora. Farlowiella (Acrogenospora) is placed in Pleosporomycetidae genera incertae sedis in Boehm et al. (2009b), Schoch et al. (2009), Hyde et al. (2013), Wijayawardene et al. (2018). However, in the present study, Acrogenospora (type: Acrogenospora sphaerocephala) groups in Minutisphaeraceae /Minutisphaerales clade. Raja et al. $(2013,2015)$ showed that Acrogenospora sphaerocephala (CBS 206.36) grouped in a clade close to Minutisphaerales (Ferrer et al. 2011, Raja et al. 2013). Minutisphaera is the type genus of Minutisphaeraceae and differs from Acrogenosporaceae in having erumpent to superficial, pseudothecioid or apothecioid ascomata with ostioles, a thin-walled peridium and clavate, fusiform to ellipsoidal, multiguttulate ascospores with a gelatinous sheath. However, Acrogenosporaceae has hysterothecial ascomata with thick-walls, a prominent sunken slit and 1-celled, pedicellate, hyaline or moderately pigmented ascospores. Therefore, based on morphological and phylogenetic differences we placed Acrogenospora sp. in new family Acrogenosporaceae in the order Minutisphaerales.

Gloniales Jayasiri \& K.D. Hyde, ord. nov.

Index Fungorum number: IF553002; Facesoffungi number: FoF03250

Saprobic or ectomycorrhizal on bark, wood, pine cone or soil. Sexual morph: Hysterothecia dark, erumpent to superficial, progressively dichotomously branched or scattered to gregarious, Peridium wide, thick, carbonaceous and brittle when dry. Pseudoparaphyses cellular, septate, persistent, wide, hyaline, branched with darkened apices, in a gel matrix. Asci 8-spored, fissitunicate, clavate to cylindrical. Ascospores, overlapping biseriate, hyaline, lightly pigmented to dark brown, 2-celled to muriform. Asexual morph: psiloglonium stygium-like (Boehm et al. 2009a, Jayasiri et al. 2017).

Type family - Gloniaceae (Corda) E.W.A. Boehm, C.L. Schoch \& J.W. Spatafora, Mycol Res. 113(4): 468 (2009)

Notes - Boehm et al. (2009b) introduced the family Gloniaceae based on the genus Glonium and accommodated in Pleosporomycetidae family, incertae sedis. Boehm et al. (2009a) added the genus Cenococcum to this family. Recently, Purpurepithecium was added to the family by Jayasiri et al. (2017). In the present study, we place this family in a new order Gloniales, which forms a distinct sister clade to the Mytilinidiales clade (Fig. 1) and is also supported by several significant 
morphological differences. However, this is not supported in the protein tree of RPB2 where as Purpurepithecium forming a separate clade (Fig. 3). Mytilinidiales and Gloniales morphologically differ as follows: Mytilinidiales (type: Mytilinidion) is characterized by fragile persistent carbonaceous ascomata, which range from globoid to obovoid to strongly laterally compressed erect, bivalve shell-shaped structures, standing on edge, with lateral walls more or less connivant, and extended vertically; Gloniales (type: Glonium) has modified hysterothecia, progressively dichotomously branched or scattered to gregarious. Lumbsch \& Huhndorf (2010) placed the closely related Gloniaceae in Mytilinidiales based to multigene data. However, Boehm et al. (2009a, b), Schoch et al. (2009) placed it in Pleosporomycetidae, family incertae sedis, because of the highly divergent morphology associated with the genus Glonium. Spatafora et al. (2012) provided strong multigene phylogenetic evidence that Cenococcum is a member of Gloniaceae (incertae sedis, Pleosporomycetidae, Dothideomycetes).

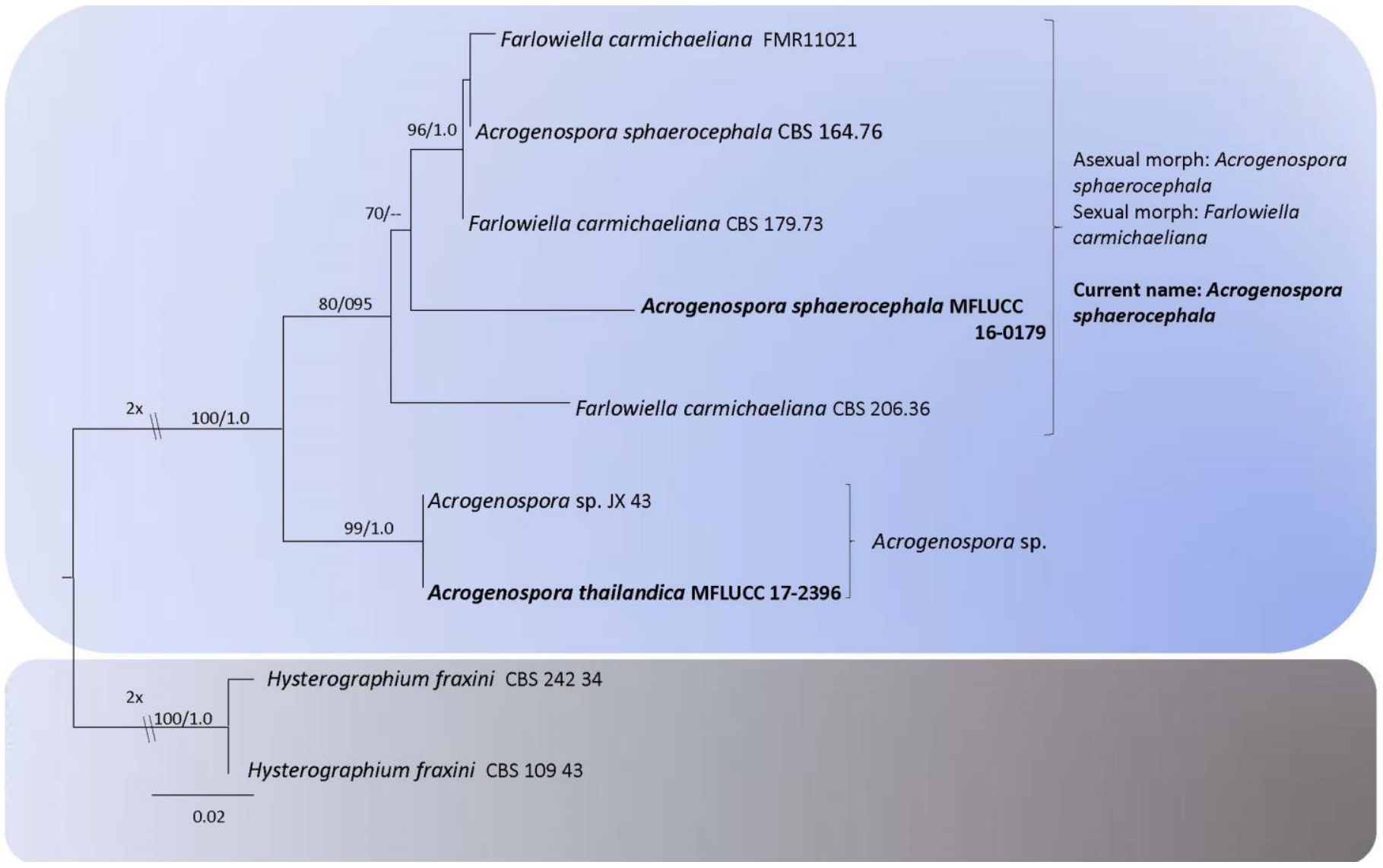

Figure 2 - Simplified phylogram showing the best RAxML maximum likelihood tree obtained from the combined multigene (LSU, SSU, RPB2 and TEF1) matrix of nine taxa representing the family Acrogenosporaceae with their original name. Hysterographium fraxini (CBS 242.32 and CBS 109.43) is selected as the outgroup taxon.ML bootstrap support equal or grater than above 70 $\%$ and Bayesian posterior probabilities above 0.95 are given near to each branch.

Purpurepithecium minus (N. Amano) Jayasiri \& K.D. Hyde, comb. nov.

Index Fungorum number: IF554452; Facesoffungi number: FoF04576

$\equiv$ Hysterographium minus N. Amano, Trans. Mycol. Soc. Japan 24(3): 293 (1983)

Notes - Hysterographium minus (JCM 2758) clusters with Purpurepithecium murisporum and is distantly placed from the Hysterographium clade in our multigene phylogenetic analyses. Hysterographium minus is therefore placed in new combination as Purpurepithecium minus, based on morphological and phylogenetic similarities. Hysterographium minus is morphologically similar to Purpurepithecium murisporum in having pigmented dictyospores with a brick-red epithecium (Boehm et al. 2009a, Jayasiri et al. 2017). 
Hysteriales Lindau, Natürl. Pflanzenfam.: 265 (1896)

Notes - The order Hysteriales was introduced by Lindau (1897) and has been placed among the pyrenomycetes and the discomycetes at different times (Rehm 1897). Molecular data places Hysteriales in Dothideomycetes (Boehm et al. 2009a, b, Shearer et al. 2009, Suetrong et al. 2009, in this study). Furthermore, Hysteriales is strongly supported with specific morphological features and multigene phylogenetic analysis of LSU, SSU, RPB2 and TEF1 gene sequence data.

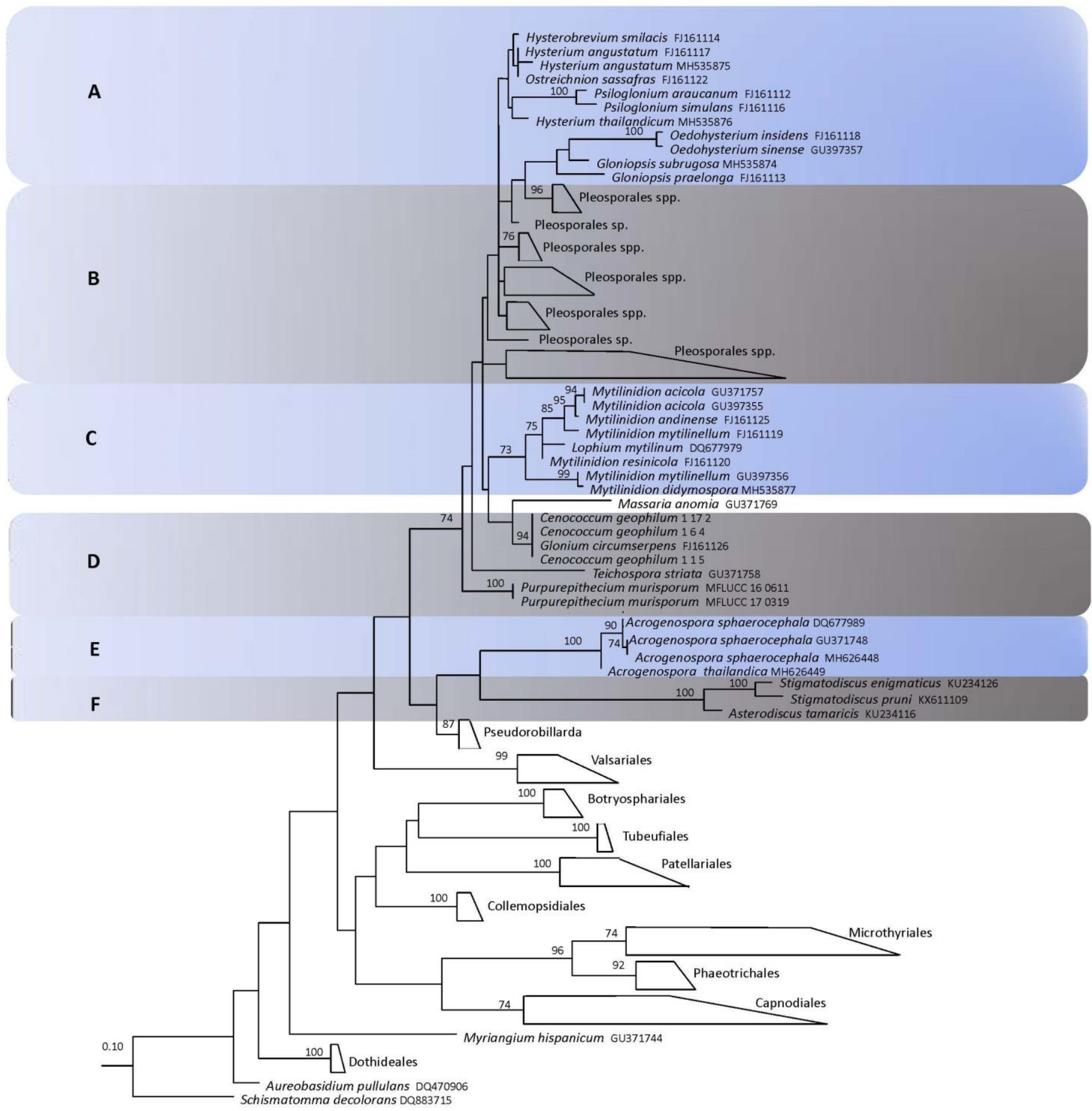

Figure 3 - Simplified phylogram showing the best protein RAxML maximum likelihood tree obtained from the RPB2 gene product translated to amino acid sequences. Major orders in Dothideomycetes are represented by the 95 taxa with available sequence data. Arthoniomycetes (Schismatomma decolorans, DQ883715) was selected as the outgroup. MLBS equal or above $70 \%$ are given near to each branch. Other lineages were collapsed to ordinal level. 
Hysteriaceae Chevall. 1826, Flore Générale des Environs de Paris 1: 432 (1826)

Notes - In recent morphological and phylogenetic studies (Boehm et al. 2009a, b, de Almeida et al. 2014), this family comprises nine genera: Gloniopsis, Graphyllium, Hysterium, Hysterobrevium, Hysterodifractum, Oedohysterium, Ostreichnion, Psiloglonium and Rhytidhysteron based on morphological and phylogenetic data. However only based on morphology Actidiographium, Gloniella, Hysterocarina and Hysteropycnis also belong to family Hysteriaceae (Boehm et al. 2009a, b, Wijayawardene et al. 2018). In this study, we propose Hysterium curtisii (Basionym) as the current name for Ostreichnion curtisii, because genus Ostreichnion type (O. sassafras) is distantly clades with $O$. curtisii. In addition to study of Tibpromma et al. 2017 also confirmed this placement introducing a new species Hysterium centramurum which is clade with Ostreichnion curtisii. Thambugala et al. (2016) have outlined the genus Rhytidhysteron and redefined the genus in Hyde et al. (2017).

Gloniopsis subrugosa (Cooke \& Ellis) E. Boehm \& C.L. Schoch, Studies in Mycology 64: 65 (2009)

Basionym: Hysterium subrugosum Cooke \& Ellis, Grevillea 5: 54.1876.

=Hysterographium subrugosum (Cooke \& Ellis) Sacc., Sylloge Fungorum 2: 780 (1883)

Facesoffungi number: FoF04582

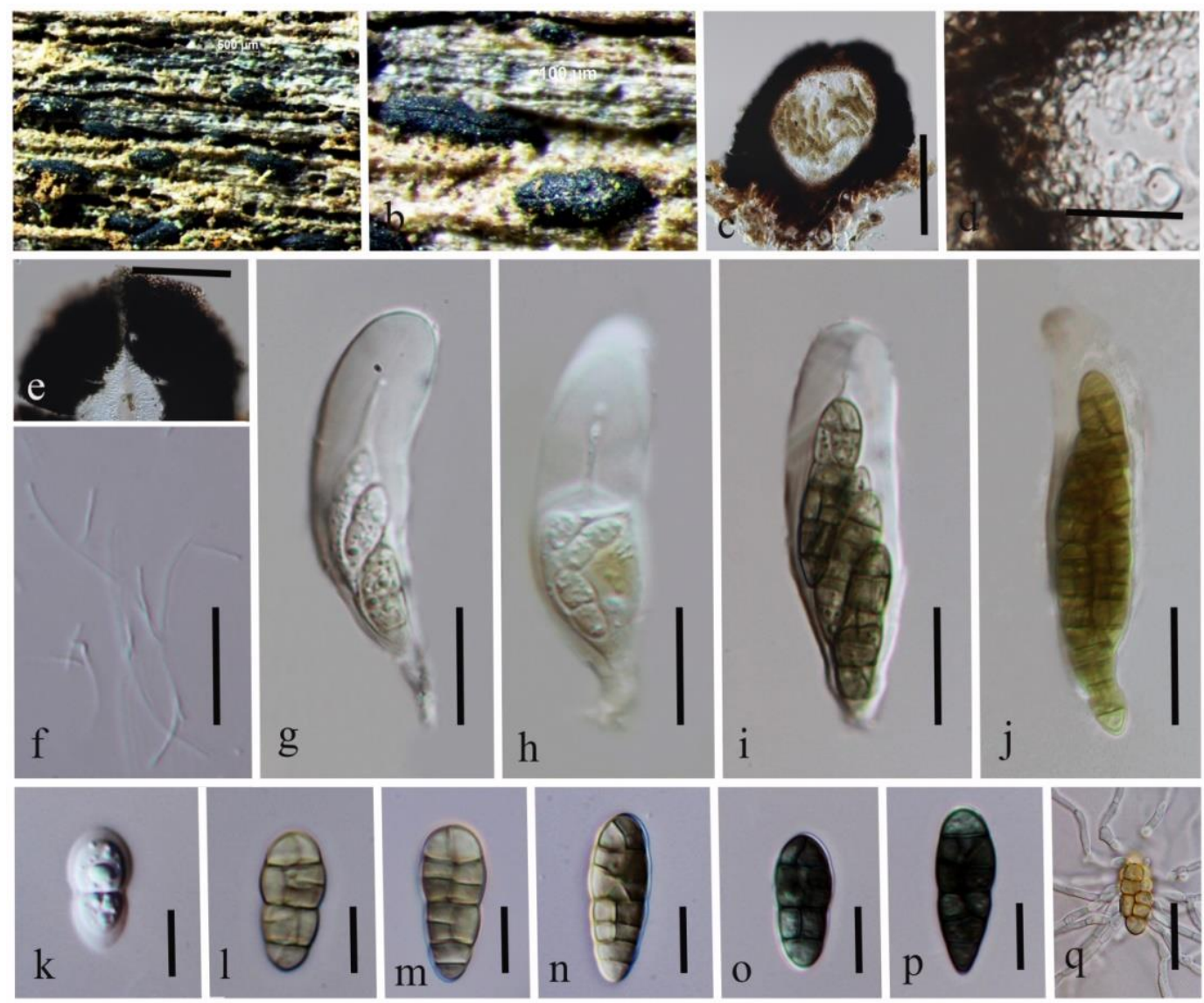

Figure 4 - Gloniopsis subrugosa. a-b Hysterothecia on host. c Vertical section through hysterothecium. d Peridium. e Section through the longitudinal slit. f Pseudoparaphyses. g-j Asci with 8-spores. $\mathrm{k}-\mathrm{p}$ Ascospores. q Germinated spore. Scale bars: $\mathrm{c}=100 \mu \mathrm{m}, \mathrm{d}, \mathrm{e}=30 \mu \mathrm{m}$, $\mathrm{f}=10 \mu \mathrm{m}, \mathrm{g}, \mathrm{h}=20 \mu \mathrm{m}, \mathrm{k}-\mathrm{q}=30 \mu \mathrm{m}$.

Saprobic on dead wood. Sexual morph: Hysterothecia 347-371 $\mu \mathrm{m}$ high, 199-232 $\mu \mathrm{m}$ diam., 800-1000 $\mu \mathrm{m}$ long $(\bar{x}=365 \times 220 \times 900 \mu \mathrm{m}, \mathrm{n}=10)$, navicular, straight to flexuous, with tapered ends, erumpent to superficial, scattered, with a prominent longitudinal slit. Peridium 24-33 $\mu \mathrm{m}$ 
wide $(\bar{x}=29 \mu \mathrm{m}, \mathrm{n}=10)$, carbonaceous, brittle, heavily pigmented, of small, prosenchymatous cells. Hamathecium 1-1.5 $\mu \mathrm{m}$ wide, persistent, septate, hyaline, not branched above the asci, borne in a gelatinous matrix. Asci 50-75 $\mu \mathrm{m}$ high $\times 13-16 \mu \mathrm{m}$ diam. $(\bar{x}=68 \times 14 \mu \mathrm{m}, \mathrm{n}=25), 8$-spored, bitunicate, cylindrical to clavate, short-pedicels, with a prominent apical ocular chamber. $118-20 \times$ 13-16 $\mu \mathrm{m},(\bar{x}=19 \times 15 \mu \mathrm{m}, \mathrm{n}=30)$, crowded to biseriate, immature hyaline, mature brown to greenish brown pigmented dictyosporus, with 7-11 transverse and 1-2 vertical septa, hardly constricted at septa, slightly asymmetric in outline. Asexual morph: Pycnidia 230-260 $\mu \mathrm{m}$ high $\times$ 110-190 $\mu \mathrm{m}$ diam $(\bar{x}=245 \times 180 \mu \mathrm{m}, \mathrm{n}=5)$, globose to subglobose, on upper surface of the agar, olivaceous to brick coloured, then olivaceous black, solitary or aggregated, lacking setose-like outgrowths, with or without distinct ostiole, pycnidial wall consisting brown outer layers to hyaline inner cell layers. Conidiogenous cells $10-12 \times 2-3 \mu \mathrm{m}(\bar{x}=11 \times 2.5 \mu \mathrm{m}, \mathrm{n}=10)$, ampulliform to filiform. Conidia 4-6 $\times 2-3 \mu \mathrm{m}(\bar{x}=5 \times 2.5 \mu \mathrm{m}, \mathrm{n}=30)$, ellipsoidal to allantoid, greenish brown, aseptate.

Culture characteristics - Colonies on MEA attaining 20-30 mm diam. after 7 days at $25^{\circ} \mathrm{C}$, with irregular edge, brown coloured, with dense aerial mycelium on the surface with black, gregarious conidiomata; reverse black.
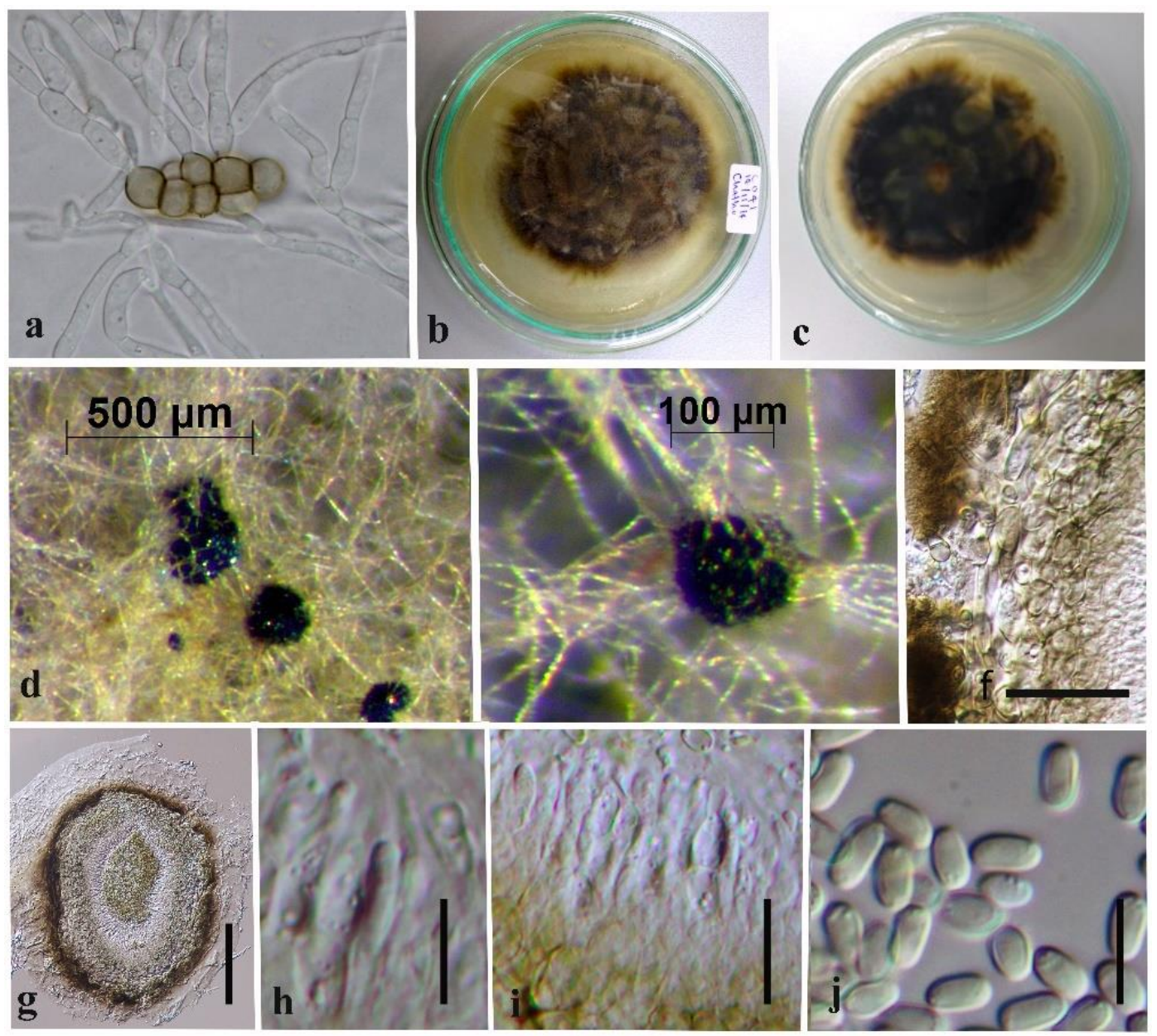

Figure 5 - Gloniopsis subrugosa asexual morph. a Germinated spore. b-c Culture from above and reverse. d, e Fruiting body in culture. $f$ Peridium. g Vertical section of conidioma. h, i Conidiogenous cells. j Conidia. Scale bars: $f=30 \mu \mathrm{m}, \mathrm{g}=100 \mu \mathrm{m}, \mathrm{h}, \mathrm{i}=20 \mu \mathrm{m}, \mathrm{j}=10 \mu \mathrm{m}$.

Material examined - THAILAND, Doi Mae Salong on dead wood, 5 October 2014, Subashini C.Jayasiri, C 041 (MFLU 16-2984; HKAS96308), living cultures MFUCC 14-1179.

Known distribution - Cuba (Boehm et al. 2009b), Kenya (Boehm et al. 2009b), South Africa (van der Linde 1992) and Thailand (this study). 
Notes - The genus Gloniopsis was introduced by Boehm et al. (2009b). This genus is characterized by multi-septate, hyaline to yellow dictyospores, with one or more longitudinal septa. Currently, there are six species in this genus with morphological and molecular data (Boehm et al. 2009a, b, Hyde et al. 2016). Index Fungorum (2018) lists 66 species epithets under Gloniopsis. However, most of these epithets have been synonymized under a few taxon accounts and some of them do not have molecular data for DNA based comparisons. Three Gloniopsis subrugosa strains (GKM 1214, SMH 557 and CBS 123346) are comprised and there were no any morphological differences. However, in the multigene phylogenetic analysis Gloniopsis subrugosa (CBS 123346) distantly associated with other two strains with genetic heterogeneity within the taxon (Boehm et al. 2009b). Our isolate also do not have any distinct morphological features and clade with Gloniopsis subrugosa GKM 1214 and SMH 557. Therefore, in here we have documented a new record of Gloniopsis subrugosa from Thailand. In previous studies Gloniopsis subrugosa was recorded from Cuba (SMH 557), Kenya (GKM 1214) and South Africa (CBS 123346) (Boehm et al. 2009a).

Hysterium angustatum Alb. \& Schwein., Consp. fung. (Leipzig): 55 (1805)

Fig. 6

Facesoffungi number: FoF04579
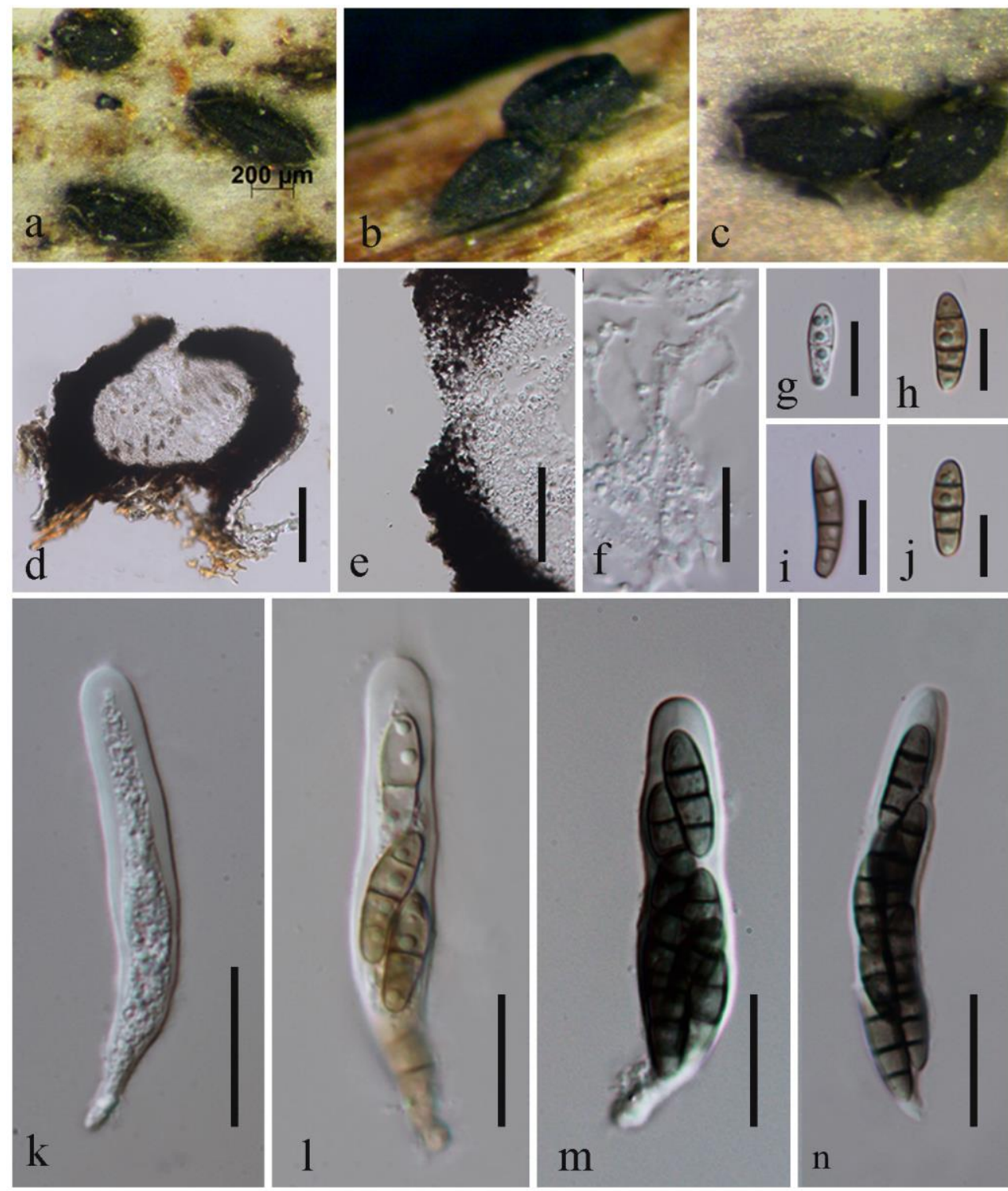

Figure 6 - Hysterium angustatum. a-c View of hysterothecia on host surface. d Section through hysterothecium. e Peridium. f Pseudoparaphyses. $\mathrm{g}-\mathrm{j}$ Ascospores. $\mathrm{k}-\mathrm{m}$ Asci. Scale bars: $\mathrm{d}=100$ $\mu \mathrm{m}, \mathrm{e}=50 \mu \mathrm{m}, \mathrm{g}-\mathrm{j}=10 \mu \mathrm{m}, \mathrm{k}-\mathrm{m}=20 \mu \mathrm{m}$. 
Saprobic on Rubus sp. (Rosaceae). Sexual morph: Hysterothecia 208-232 $\mu \mathrm{m}$ high $\times 256$ $284 \mu \mathrm{m}$ wide $\times 500-600 \mu \mathrm{m}$ long $(\bar{x}=218 \times 268 \times 560 \mu \mathrm{m}, \mathrm{n}=10)$, elongate and depressed conchate, scattered, superficial, base immersed in substrate, surface black, shiny, longitudinally striate, apex compressed, opening by a longitudinal slit. Peridium $40-60 \mu \mathrm{m}(\bar{x}=51, \mathrm{n}=15)$ carbonaceous, brittle, of heavily pigmented, small prosenchymatous cells. Hamathecium $0.5-1.5$ $\mu \mathrm{m}$ wide, trabeculate, aseptate, branched, pseudoparaphyses, borne in a gel matrix. Asci 59-66× 7.6-9.2 $\mu \mathrm{m}(\bar{x}=63 \times 8.6 \mu \mathrm{m}, \mathrm{n}=15), 8$-spored, bitunicate, oblong to clavate, with a short narrow pedicel, apically thickened, with a distinct ocular chamber. Ascospores $14-17 \times 4-5.3 \mu \mathrm{m}(\bar{x}=$ $15.5 \times 4.6 \mu \mathrm{m}, \mathrm{n}=25$ ), crowded to biseriate to triseriate, fusiform, hyaline when young and becoming brown at maturity, 3-septate, smooth-walled, ornamented, mucilaginous sheath absent. Asexual morph: Undetermined.

Culture characteristics - Ascospores germinating on MEA within $24 \mathrm{~h}$. slow growing at $18^{\circ} \mathrm{C}$ reaching $2 \mathrm{~cm}$ in 14 days, yellow at first, becoming ash when mature and reverse yellow.

Material examined - ITALY, Province of Forlì-Cesena [FC]), near Fiumana di Predappio, on dead aerial branch of Rubus sp. (Rosaceae), 20 January 2016, E. Camporesi, IT 2794 (MFU 160468; HKAS96320), living culture MFLUCC 16-0623.

Distribution - Kenya, New Zealand, Tennessee, United States (Boehm et al. 2009a); Italy (in this study).

Notes - In here we re-describe and illustrated of Hysterium angustatum with new a strain. This is the first report of Hysterium angustatum from Italy. Hysterium angustatum strains have little variability in their spore morphology, may be because of indicate early stages of speciation within the taxon, with sequence variation preceding morphologic change (Boehm et al. 2009a).

Hysterium doimaeensis Jayasiri \& K.D. Hyde, sp. nov.

Fig. 7

Index Fungorum number: IF554456; Facesoffungi number: FoF04581

Holotype: MFLU 16-0954

Etymology: In reference place where specimen was collected.

Saprobic on decaying wood. Sexual morph: Hysterothecia $480-550 \mu \mathrm{m}$ high, 380-420 $\mu \mathrm{m}$ diam., $600-800 \mu \mathrm{m}$ long $(\bar{x}=510 \times 400 \times 700 \mu \mathrm{m}, \mathrm{n}=10)$, scattered, superficial, base immersed in substrate, elongate and depressed conchate, surface black, shiny, longitudinally striate, apex compressed, opening by longitudinal slit. Periphyses along the slit, aseptate, hyaline, swollen, with blunt ends. Peridium 50-80 $\mu \mathrm{m}$ wide $(\bar{x}=65 \mu \mathrm{m}, \mathrm{n}=10)$, comprising carbonaceous, brittle, heavily pigmented, small, prosenchymatous cells. Hamathecium 1-1.5 $\mu \mathrm{m}$ wide, persistent, trabeculate, hyaline, aseptate, branched, borne in a gel matrix, which is brownish granular above the asci, longer than asci. Asci 139-225 $\times 22-44 \mu \mathrm{m}(\bar{x}=180 \times 36 \mu \mathrm{m}, \mathrm{n}=20)$, 8-spored, bitunicate, arising from base, oblong to clavate, with a short pedicel, apex thickened, with refractive ring around cytoplasmic protrusion. Ascospores 60-73 $\times 12-13 \mu \mathrm{m}(\bar{x}=66 \times 12.5 \mu \mathrm{m}, \mathrm{n}=30)$, crowded to biseriate, fusiform when young, oblong at maturity, hyaline to light yellow, 1-3-septate, with prominent central septum, wall greatly thickened towards the apex, wall smooth. Sheath absent. Asexual morph: Undetermined.

Culture characteristics - Ascospores germinating on MEA within 24 hours. Colonies on MEA, white, circular, smooth margin, slow growing, attaining $1 \mathrm{~cm}$ diameter within 30 days at $18^{\circ}$ $\mathrm{C}$, tightly arranged, short, aerial mycelium. Orange brownish exudates was released to the media when mycelium growing. The mycelial mats were produced erumpent, globose, thick, less stromatic, light brownish viscous droplets and later become lighter in the colour of the superficial hyphae with copious dark brown.

Material examined - THAILAND, Chiang Rai Province, Doi Mae Salong, on dead branch, 27 April 2015, Subashini C. Jayasiri, C 051 (MFLU 16-0954, holotype; HKAS96310, isotype); extype living culture, MFLUCC 16-0338, BCC

Notes - Hysterium doimaeensis resembles Hy. Curtisii and Hy. centramurum in having hysterothecia, appearing as black, scattered, superficial, carbonaceous ascomata and bitunicate asci, but Hy. curtisii differs from Hy. doimaeensis in having both vertical and transverse septate 
ascospores (Boehm et al. 2009b). Hysterium doimaeensis differs from Hy. centramurum in having smaller ascospores. Phylogenetical data also confirm that they are distinct (97\% MLBS/1.00 BPP). We have accounted base pair differences of LSU gene sequences between Hysterium centramurum, Hy. curtisii, Hy. doimaeensis and H. thailandica. Hysterium doimaeensis have 33, 30 and 35 base pair differences with $H y$. centramurum, Hy. curtisii and $H$. thailandica respectively.

\section{Key to four species of Hysterium}

1. Ascospore size more than $100 \mu \mathrm{m}$............................ Hysterium centramurum

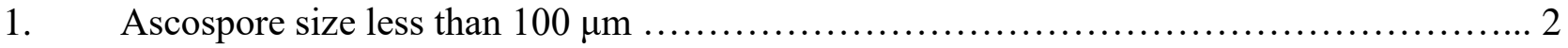

2. Ascospore size equal or less than $60 \mu \mathrm{m}$.......................................... Hysterium thailandica

2. Ascospore size more than $60 \mu \mathrm{m}$.............................................. 3

3. 1-septate, under different stains appears subdivided into numerous compartments Hysterium curtisii

4. 1-3 septate, germinated spores appear 3-septate .................. Hysterium doimaeensis

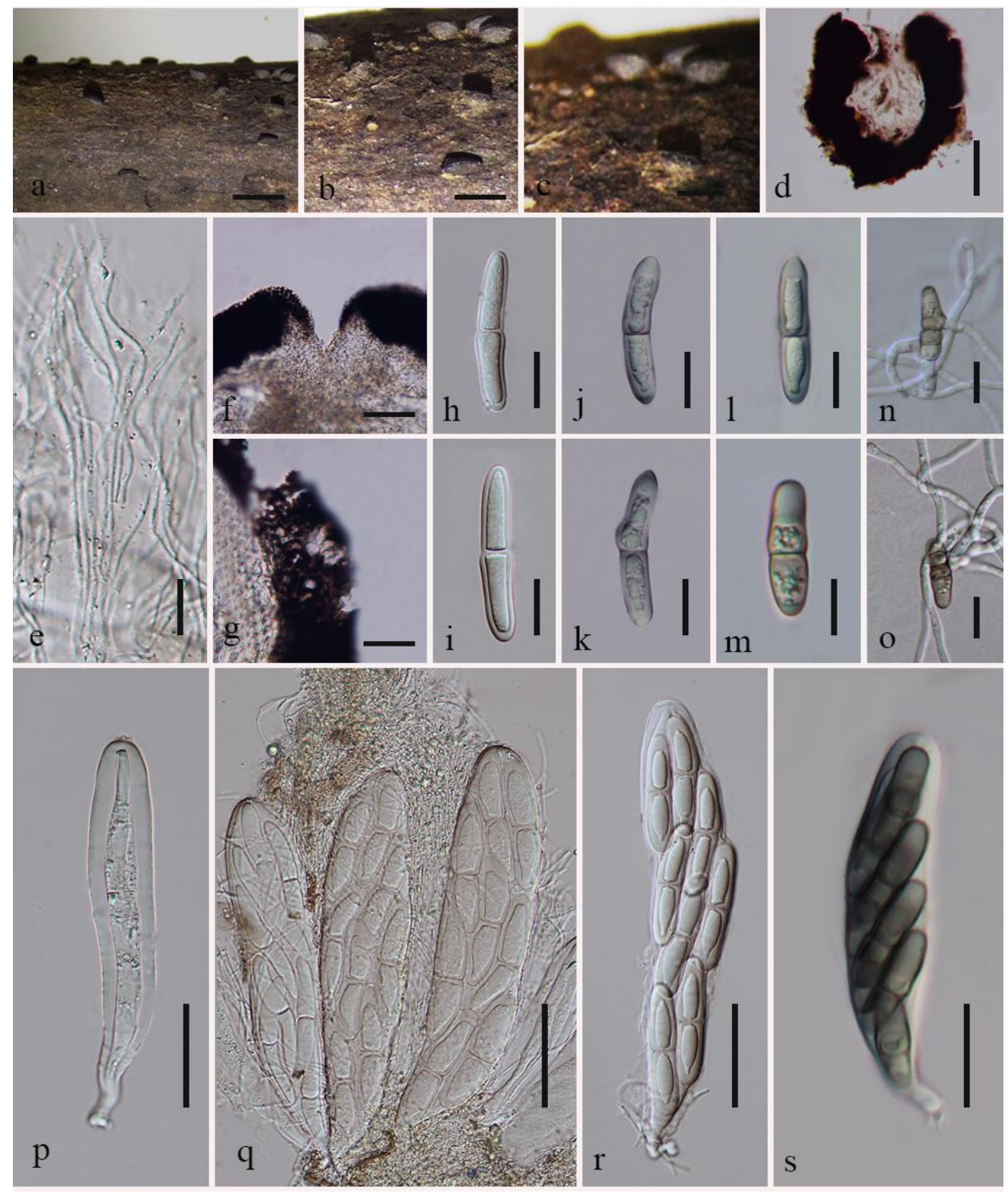

Figure 7 - Hysterium doimaeensis (holotype). a-c Hysterothecia on host surface. d Hand section of hysterothecium. e Hamathecium. f Ostiole through the longitudinal slit. $g$ Peridium. h-m Ascospores. $\mathrm{n}$, o Germinated spores. $\mathrm{p}$ Immature ascus. $\mathrm{q}-\mathrm{s}$ Asci with ascospores. Scale bars: $\mathrm{a}=1 \mathrm{~cm}, \mathrm{~b}, \mathrm{c}=500 \mu \mathrm{m}, \mathrm{d}=150 \mu \mathrm{m}, \mathrm{e}=10 \mu \mathrm{m}, \mathrm{f}, \mathrm{g}=100 \mu \mathrm{m}, \mathrm{h}-\mathrm{o}=20 \mu \mathrm{m}, \mathrm{p}-\mathrm{s}=50 \mu \mathrm{m}$. 
Hysterium thailandica Jayasiri \& K.D. Hyde, sp. nov.

Fig. 8

Index Fungorum number: IF554455; Facesoffungi number: FoF04580

Holotype: MFLU 16-2986

Etymology: In reference where the specimen was collected.

Saprobic on dead branches of an unknown plant. Sexual morph: Hysterothecia 203-350 $\mu \mathrm{m}$ high, 190-310 $\mu \mathrm{m}$ diam., 500-600 $\mu \mathrm{m}$ long $(\bar{x}=260 \times 240 \times 600 \mu \mathrm{m}, \mathrm{n}=10)$, elongate and depressed conchate, solitary, scattered, superficial, base immersed in substrate, black, shiny, longitudinally striate, apex compressed, opening by longitudinal slit. Peridium $22-60 \mu \mathrm{m}$ wide $(\bar{x}$ $=45 \mu \mathrm{m}, \mathrm{n}=10$ ), carbonaceous, brittle, thick-walled, heavily pigmented, of small, prosenchymatous cells. Hamathecium 1-1.5 $\mu \mathrm{m}$ wide, dense, filamentous, trabeculate, cellular pseudoparaphyses, aseptate, embedded in a hyaline gelatinous matrix. Asci 155-210 × 19-34 $\mu \mathrm{m}$ $(\bar{x}=180 \times 27 \mu \mathrm{m}, \mathrm{n}=20), 8$-spored, bitunicate, oblong to clavate, with a short pedicel, apically thickened, with a distinct ocular chamber. Ascospores 40-60 $\times 8-12 \mu \mathrm{m}(\bar{x}=52 \times 10 \mu \mathrm{m}, \mathrm{n}=30)$, overlapping bi-seriate to parallel, ellipsoidal to fusiform with rounded ends, hyaline to light yellow, 1-septate when young, becoming multiseptate, deeply constricted at the central septum, nearly symmetrical, smooth-walled, guttulate. Asexual morph: Undetermined.
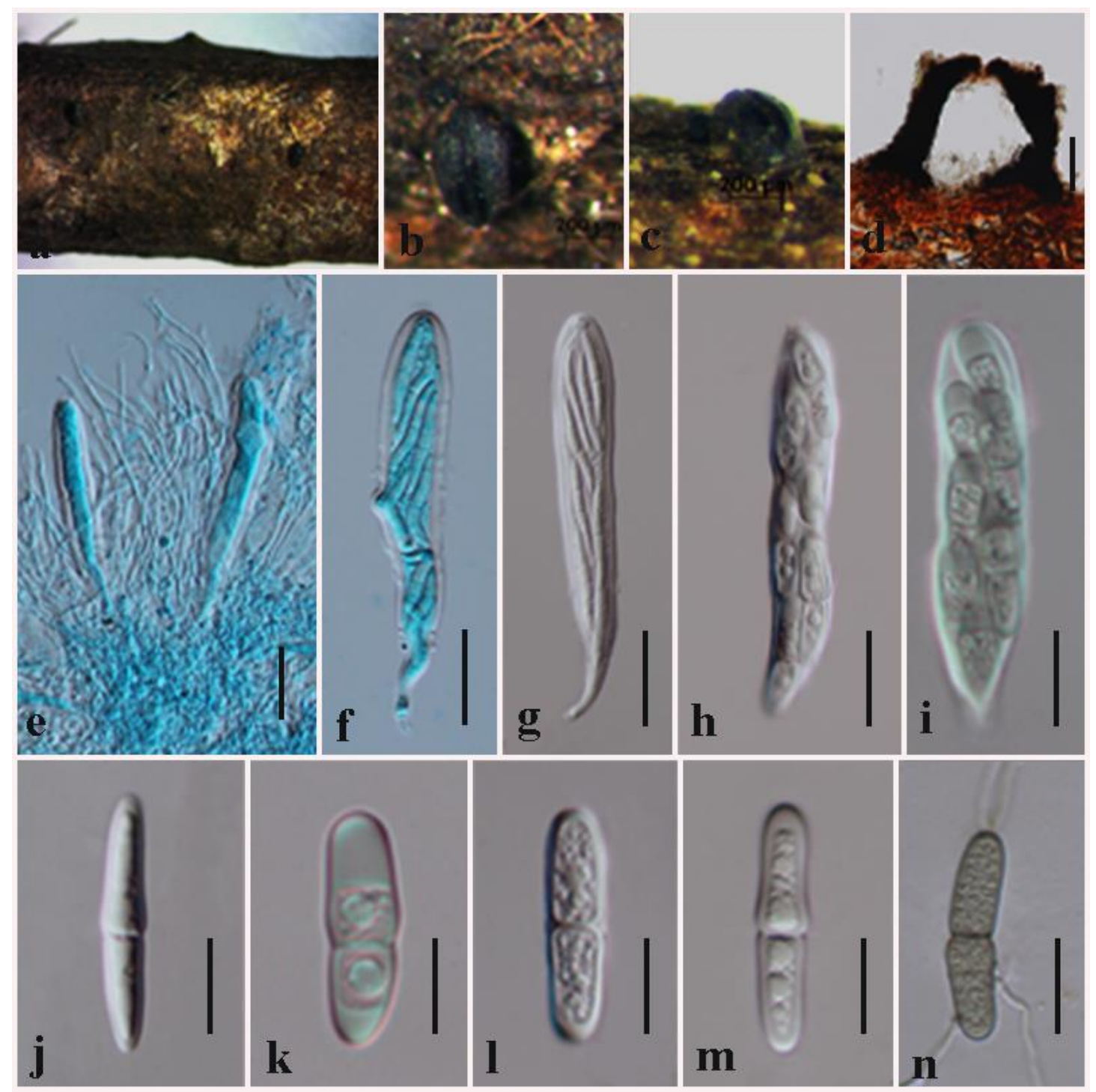

Figure 8 - Hysterium thailandica (holotype). a Hysterothecia on host surface. b, c View of hysterothecium on the host surface. d Section through the longitudinal slit. e Immature asci and pseudoparaphyses stain with Lactophenol cotton blue. $f, g$ Immature asci. $h$, $i$ Asci. j-m Ascospores. $n$ Germinated ascospore. Scale bars: $d=100 \mu \mathrm{m}, \mathrm{e}-\mathrm{i}=50, \mathrm{j}-\mathrm{n}=20 \mu \mathrm{m}$. 
Culture characteristics - Ascospores germinating on malt extract agar (MEA) within 24 hours and germ tubes produced from ascospore (Fig. 7). Colonies growing slowly on MEA, reaching 4 $\mathrm{mm}$ in 1 weeks at $18^{\circ} \mathrm{C}$, brown to dark brown. Mycelium superficial and partially immersed, branched, septate, hyaline to pale brown, smooth.

Material examined - THAILAND, Chiang Mai Province, dead stem of unknown plant, 22 July 2015, Subashini C. Jayasiri, C 073 (MFLU 16-2986, holotype; HKAS96311, isotype); ex-type living culture, MFLUCC 16-0338, BCC

Notes - Hysterium thailandica fits with the generic concept of the genus, Hysterium in having pigmented versicolorous or concolorous asymmetric phragmospores, three- or more transversely-septate, borne in hysterothecia (Boehm et al. 2009b). This species is phylogenetically and morphologically close to Hy. centramurum, Hy. curtisii and Hy. doimaeensis. A comparison of the morphological features of these four species is presented in the key. Hysterium thailandica groups in a sister clade to Hy. centramurum with $75 \%$ MLBS statistical support. Hy. centramurum and $H$. thailandica are different from, $H$. thailandica in having short and narrow ascospores $(52 \times$ $10 \mu \mathrm{m}$ vs. $125 \times 23 \mu \mathrm{m})$ (Tibpromma et al. 2017). We have considered base pair differences of LSU gene sequences between Hysterium centramurum, Hy. curtisii, Hy. doimaeensis and H. thailandica. Hysterium thailandica have 8,11 and 35 base pair differences with Hy. centramurum, Hy. curtisii and Hy. doimaeensis respectively.

Hysterobrevium hakeae Jayasiri, E.B.G. Jones \& K.D. Hyde, sp. nov.

Fig. 9

Index Fungorum number: IF554453; Facesoffungi number: FoF04577

Etymology: With reference to host genus "Hakea"

Holotype: MFLU 16-2987

Saprobic on exocarp of Hakea actites (Proteaceae) fruits. Sexual morph: Hysterothecia 234$345 \mu \mathrm{m}$ high $\times 285-392 \mu \mathrm{m}$ diam. $\times 800-1000 \mu \mathrm{m}$ long $(\bar{x}=296 \times 337 \times 900 \mu \mathrm{m}, \mathrm{n}=10)$, elongate, superficial, gregarious, longitudinally striate, opening by a longitudinal slit. Periphyses along the slit, v-shaped, with brown cells. Peridium 27-67 $\mu$ mwide $(\bar{x}=49 \mu \mathrm{m})$, carbonaceous, brittle, heavily pigmented. Hamathecium $1-1.5 \mu \mathrm{m}$ wide, trabeculate, hyaline, septate, branched, longer than asci. Asci (48-) 65-105 × 10-14 $\mu \mathrm{m}(\bar{x}=84.5 \times 12 \mu \mathrm{m}, \mathrm{n}=20), 8$-spored, bitunicate, oblong to clavate, with a short pedicel, apically thickened. Ascospores $18-22 \mu \mathrm{m} \times(5.4-) 8.5-11.5$ $\mu \mathrm{m}(\bar{x}=20 \times 10 \mu \mathrm{m}, \mathrm{n}=20)$, uniseriate to biseriate, oblong, with prominent median septate, hyaline, thick-walled, wall smooth, sheath absent. Asexual morph: Undetermined.

Material examined - AUSTRALIA, Melbourne, Mornington Peninsula, on Hakea actites fruits (Proteaceae), 10 March 2015, E.B.G. Jones, GJ 106 (MFLU 16-2987, holotype); (isotype in PDD)

Notes - Hysterobrevium comprises three species with morphological and molecular data: Hysterobrevium constrictum (N. Amano) E.W.A. Boehm \& C.L. Schoch, H. mori (Schwein.) E. Boehm \& C.L. Schoch and H. smilacis (Schwein.) E. Boehm \& C.L. Schoch. Hysterobrevium hakeae fits the generic concept of Hysterobrevium in having navicular hysterothecia with a prominent longitudinal slit, bitunicate, cylindrical to clavate asci, ovoid to obovoid hyaline dictyospores with either obtuse or acuminate ends and ascospores constricted at the median septum. In the multigene phylogenetic analyses Hy. hakeae groups with $H$. constrictum (SMH 5211.1) with high statistical support (94\% MLBS/1.00 BPP). Hysterobrevium hakeae shares similar characters of the genus Hysterobrevium, but differs from $H$. constrictum in having ascospores with a sheath and longitudinal septa of $H$. constrictum (Boehm et al. 2009b).

Hysterobrevium rosae Jayasiri, Camporesi \& K.D. Hyde, sp. nov.

Figs 10, 11

Index Fungorum number: IF554454; Facesoffungi number: FoF04578

Holotype: MFLU 16-2989

Etymology: Referring to the host genus Rosa.

Saprobic on Rosa canina (Rosaceae). Sexual morph: Hysterothecia 180-240 $\mu \mathrm{m}$ high, 150 $200 \mu \mathrm{m}$ diam., 500-1500 $\mu \mathrm{m}$ long $(\bar{x}=210 \times 175 \times 1200 \mu \mathrm{m}, \mathrm{n}=10)$, erumpent, ellipsoidal, 
oblong, linear or cylindrical, base consisting of epidermis or periderm cells, longitudinally striate, navicular with tapering ends. Peridium $30-60 \mu \mathrm{m}$ wide $(\bar{x}=47 \mu \mathrm{m})$, carbonaceous and brittle when dry, narrower at base within the substrate, widest at the mid-point. Hamathecium $0.5-1 \mu \mathrm{m}$ wide, cellular, septate, persistent, hyaline, apically thickened, branched and forming an epithecium in a gelatinous matrix above the ascal layer. Asci $70-83 \times 12-15 \mu \mathrm{m}(\bar{x}=78 \times 13 \mu \mathrm{m}, \mathrm{n}=20)$, 8spored, bitunicate, cylindrical to clavate, short-stipitate. Ascospores $18-22 \times 5-8 \mu \mathrm{m}(\bar{x}=20 \times 6$ $\mu \mathrm{m}, \mathrm{n}=20$ ), uniseriate to biseriate, hyaline, dictyosporous, asymmetric, with acuminate ends, with 6-7 vertical and 2-4 longitudinal septa, constricted at central septum, gelatinous sheath appears when mature. Asexual morph: Conidiomata as irregular locules, brown to pale brown, solitary, Conidiogenous cells 5-8 $\times 1.5-2 \mu \mathrm{m}$, enteroblastic, phialidic, globose to flask-shaped, hyaline, thin-walled. Conidia 2.5-4 × 1-2 $\mu \mathrm{m}$, fusiform with slightly curved apex and refractive base.
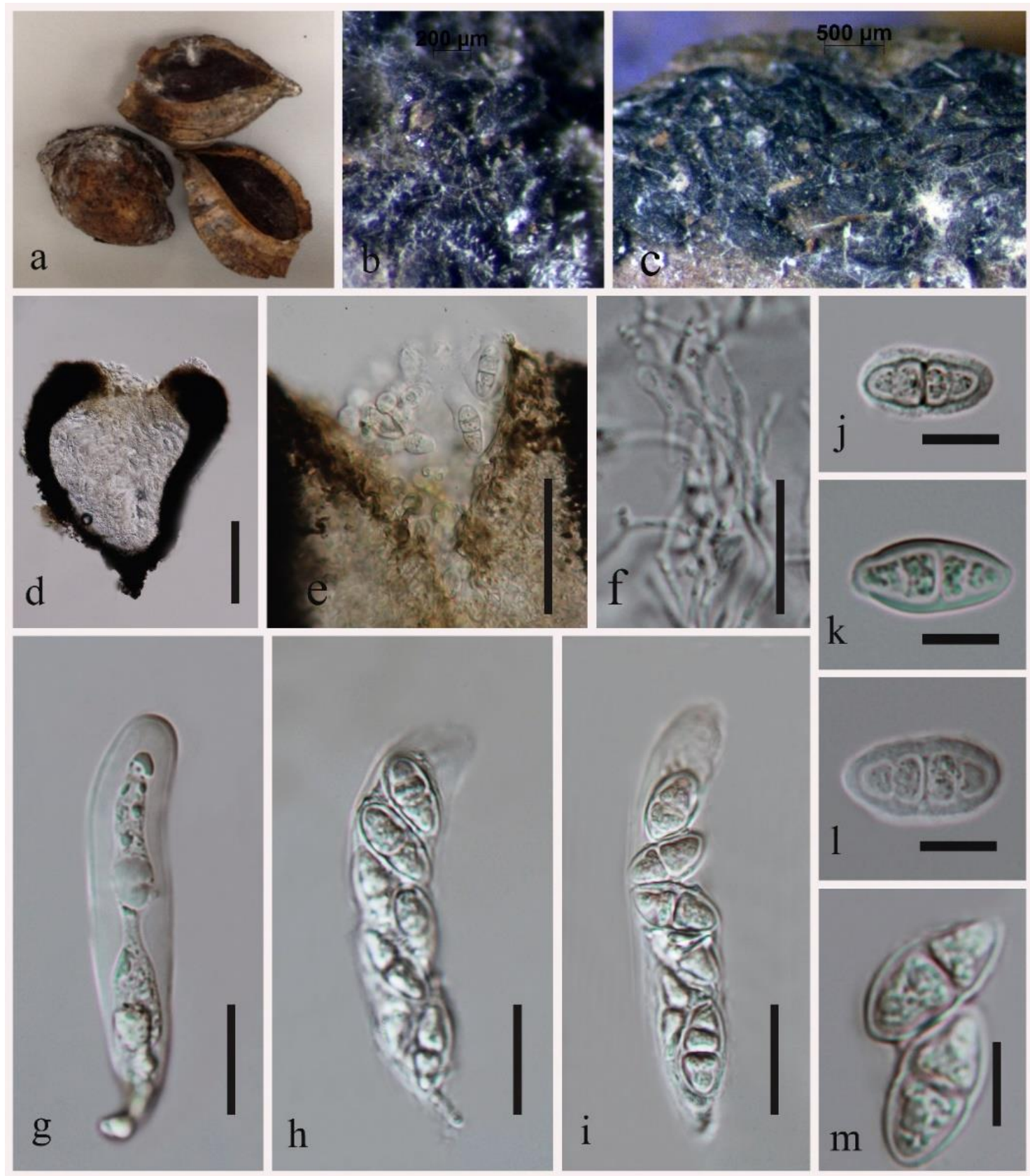

Figure 9 - Hysterobrevium hakeae (holotype). a Host fruits. b, c Hysterothecia on exocarp of seed. $\mathrm{d}$ Section through hysterothecia. e Section through the slit. f Hamathecium. $\mathrm{f}-\mathrm{h}$ Immature and mature asci. $\mathrm{i}-1$ Ascospores. Scale bars: $\mathrm{d}=100 \mu \mathrm{m}, \mathrm{e}=50 \mu \mathrm{m}, \mathrm{f}=10 \mu \mathrm{m}, \mathrm{g}-\mathrm{i}=30 \mu \mathrm{m}$, $\mathrm{i}-1=10 \mu \mathrm{m}$. 
Culture characteristics - Colonies on MEA attaining 20-30 mm diam. after $7 \mathrm{~d}$ at $25{ }^{\circ} \mathrm{C}$, with irregular pale brown edge, with dense aerial mycelium on the surface with brown, reverse similar in colour.

Material examined - ITALY, Forlì-Cesena Province [FC]), near Pieve Salutare - Castrocaro Terme, on a dead aerial branch of Rosa canina (Rosaceae), 15 June 2014, Erio Camporesi, IT 86-B (MFLU 16-2989, holotype; HKAS96318, isotype); ex-type living cultures MFUCC 14-0551(type), 14-0552, BCC.
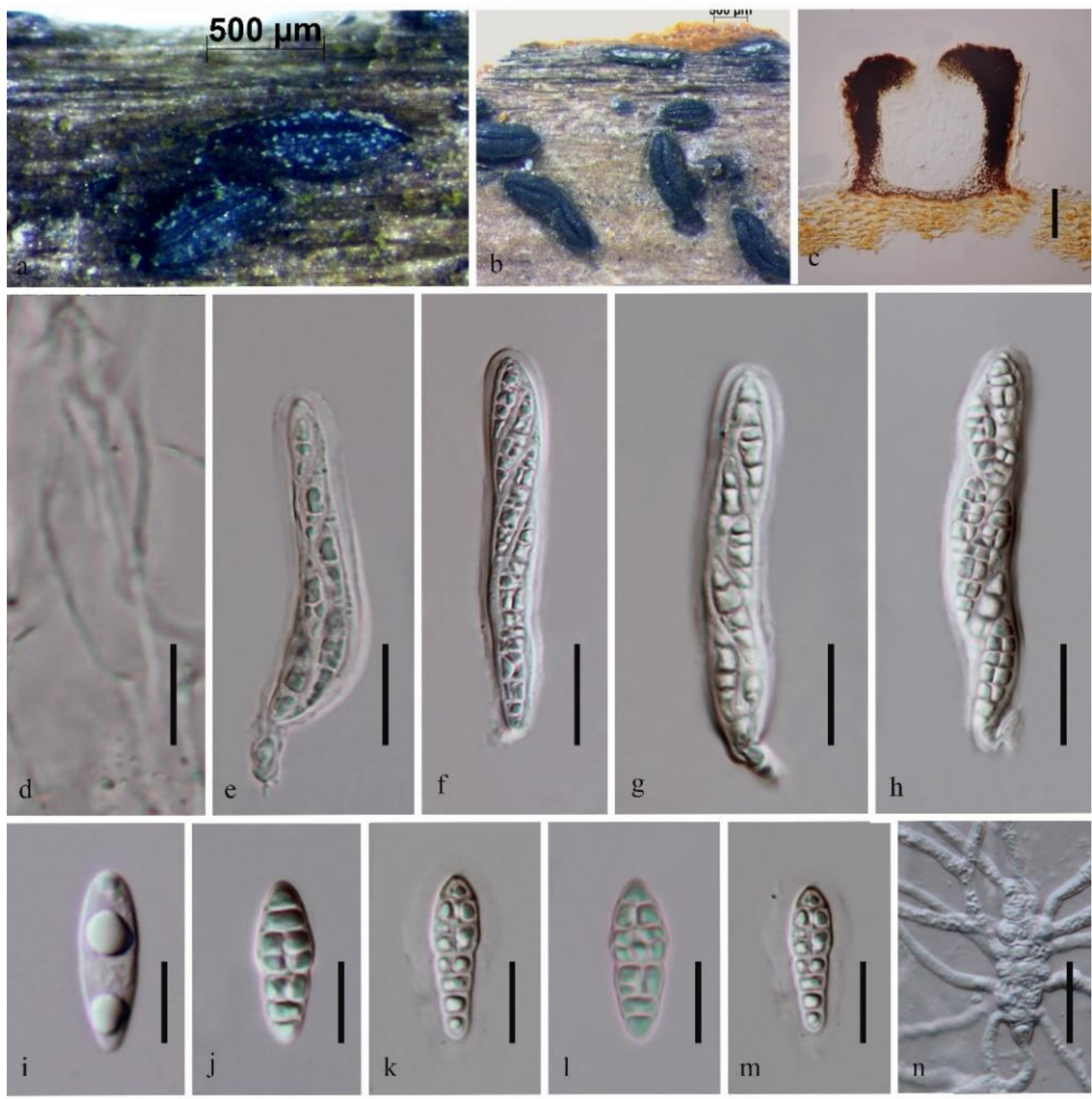

Figure 10 - Hysterobrevium rosae (holotype). a-b Hysterothecia on host. c Vertical section through hysterothecium. d Pseudoparaphyses. e-h Asci with 8-spores. i-m Ascospores. $n$ Germinated ascospore. Scale bars: $\mathrm{c}=50 \mu \mathrm{m}, \mathrm{d}, \mathrm{f}, \mathrm{g}, \mathrm{i}-\mathrm{n}=20 \mu \mathrm{m}, \mathrm{e}=10 \mu \mathrm{m}$.

Notes - Hysterobrevium rosae fits the generic concept of Hysterobrevium in having navicular, erumpent and partially embedded hysterothecia, longitudinally striate on the surface of ascomata and a prominent longitudinal slit, cylindrical to clavate asci, ovoid to obovoid, pigmented or hyaline dictyospores surrounded by a gelatinous sheath, with either obtuse or acuminate ends, with 3-4(-6) transverse septa, and 1-2 longitudinal septa. Hysterobrevium rosae groups in a sister 
clade to Hy. mori, although there are morphological differences with $H y$. rosae having relatively smaller hysterothecia $(0.5-1.5 \mathrm{~mm}, 150-200 \mu \mathrm{m}, 180-240 \mu \mathrm{m}$ vs. 1-2(-3.5) $\mathrm{mm}, 220-275(-440)$ $\mu \mathrm{m}, 190-330 \mu \mathrm{m})$, shorter asci $(70-83 \times 12-15 \mu \mathrm{m}$ vs. $80-110 \times 10-18 \mu \mathrm{m})$ and hyaline ascospores. Therefore, in this study we introduce Hysterobrevium rosae as a new species from a dead branch of Rosa canina. Wanasinghe et al. (2018) have introduced a high diversity of microfungi from the genus Rosa and this is another species found on this host genus.
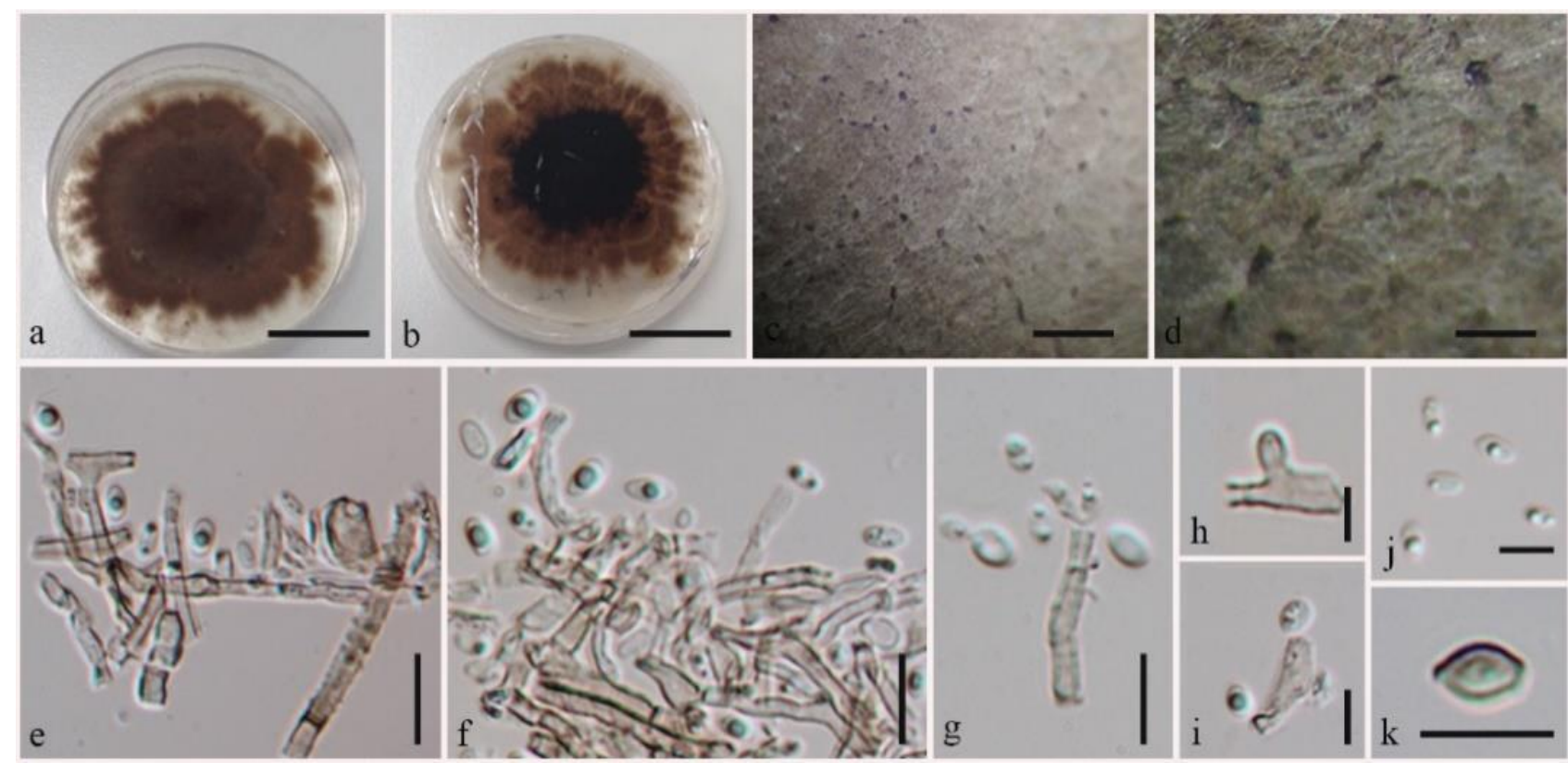

Figure 11 - Hysterobrevium rosae asexual morph in culture. a, b Culture reverse and forward view c, $d$ Asexual structures in culture. $\mathrm{e}-\mathrm{i}$ Conidia with conidiophores. j, k Conidia. Scale bars: $\mathrm{a}, \mathrm{b}=2$ $\mathrm{cm}, \mathrm{c}=500 \mu \mathrm{m}, \mathrm{d}=200 \mu \mathrm{m}, \mathrm{e}-\mathrm{g}=10 \mu \mathrm{m}, \mathrm{h}-\mathrm{k}=5 \mu \mathrm{m}$.

Psiloglonium macrosporum Thambugala, Senan. \& K.D. Hyde, in Fungal Diversity 78: 26 (2016)

Saprobic on decaying wood. Sexual morph: Hysterothecia 400-495 $\mu \mathrm{m}$ high, 450-480 $\mu \mathrm{m}$ wide, $570-1300 \mu \mathrm{m}$ long $(\bar{x}=470 \times 460 \times 921 \mu \mathrm{m}, \mathrm{n}=10)$, elongate, depressed conchate, scattered, superficial, base immersed in substrate, surface black, shiny, longitudinally striate, apex compressed, opening by a longitudinal slit. Periphyses along the slit, v-shaped, with brown cells. Peridium 50-80 $\mu \mathrm{m}(\bar{x}=68, \mathrm{n}=15)$ carbonaceous, brittle, of heavily pigmented, small, prosenchymatous cells. Hamathecium comprising $0.5-1 \mu \mathrm{m}$ wide, trabeculate, hyaline, aseptate, branched, pseudoparaphyses, borne in a gel matrix. Asci $110-145 \times 28-35 \mu \mathrm{m}(\bar{x}=130 \times 32 \mu \mathrm{m}, \mathrm{n}$ $=15)$, 4-spored, bitunicate, oblong to clavate, with a very short pedicel or apedicellate, apically thickened, with a distinct ocular chamber. Ascospores 50-100 $\times 17-24 \mu \mathrm{m}(\bar{x}=78 \times 22 \mu \mathrm{m}, \mathrm{n}=$ 25 ), crowded to biseriate, fusiform when young, oblong at maturity, hyaline when young and becoming brown at maturity, when young with 1 transverse septum, having 7 transverse and 6-7 longitudinal septa to multiseptate at maturity, deeply constricted at the central septum, smoothwalled, ornamented, surrounded by a mucilaginous sheath. Asexual morph: Undetermined.

Material examined - THAILAND, Chiang Mai Province, Mushroom Research Centre, on dead branch, July 2015, Subashini C. Jayasiri, C 083 (MFLU 16-0955; HKAS96312)

Notes - Psiloglonium macrosporum was introduced by Li et al. (2016) on a dead twig, from Thailand. Our collection from the same locality fits with the original description of $P$. macrosporum (Li et al. 2016), but we observed 4-spored asci in both the original collection and in this study. Therefore, the species description is emended to include 4-spored asci. The multigene phylogenetic analysis shows $100 \%$ similarity between the original isolate and our isolate. 

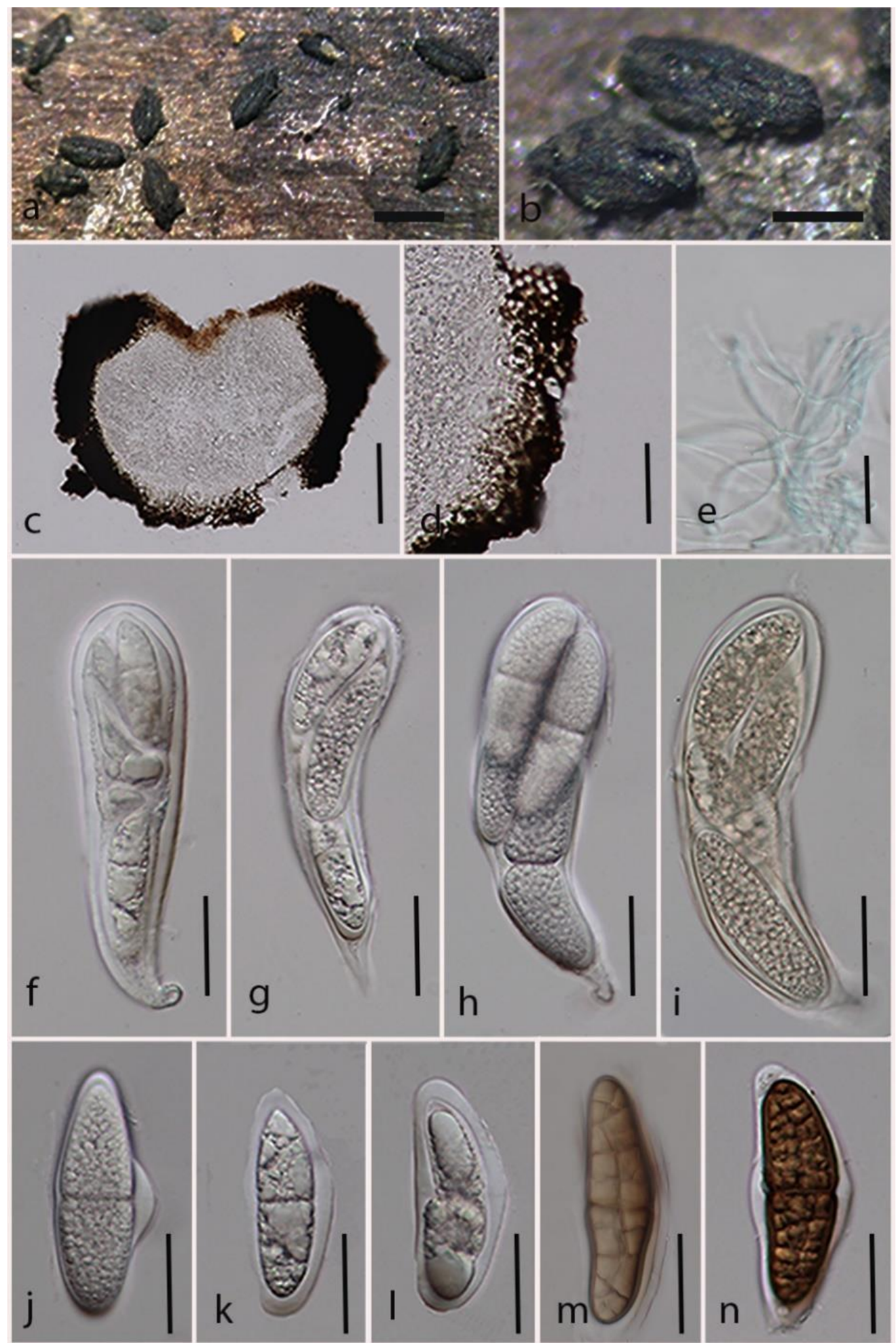

Figure 12 - Psiloglonium macrosporum. a, b View of hysterothecia on host surface. c Section through the hysterothecium. $d$ Peridium e Pseudoparaphyses. $f-i$ Asci. $j-n$ Ascospores. Scale bars: $\mathrm{c}, \mathrm{d}, \mathrm{f}-\mathrm{i}=50 \mu \mathrm{m}, \mathrm{e}=10 \mu \mathrm{m}, \mathrm{j}-\mathrm{n}=30 \mu \mathrm{m}$.

Hysterographium fraxi (Pers.) De Not. 1847

Fig. 13

Facesoffungi number: FoF04583

Saprobic on dead branch. Sexual morph: Hysterothecia 430-500 $\mu \mathrm{m}$ high, 390-490 $\mu \mathrm{m}$ diam., $700-1200 \mu \mathrm{m}$ long $(\bar{x}=480 \times 450 \times 900 \mu \mathrm{m}, \mathrm{n}=10)$, navicular, flexuous, erumpent from 
host tissue, scattered, with a prominent longitudinal slit. Peridium $80-110 \mu \mathrm{m}$ wide $(\bar{x}=90 \mu \mathrm{m})$, carbonaceous near the slit, narrower at base within the substrate, thickening not equal, base brown,
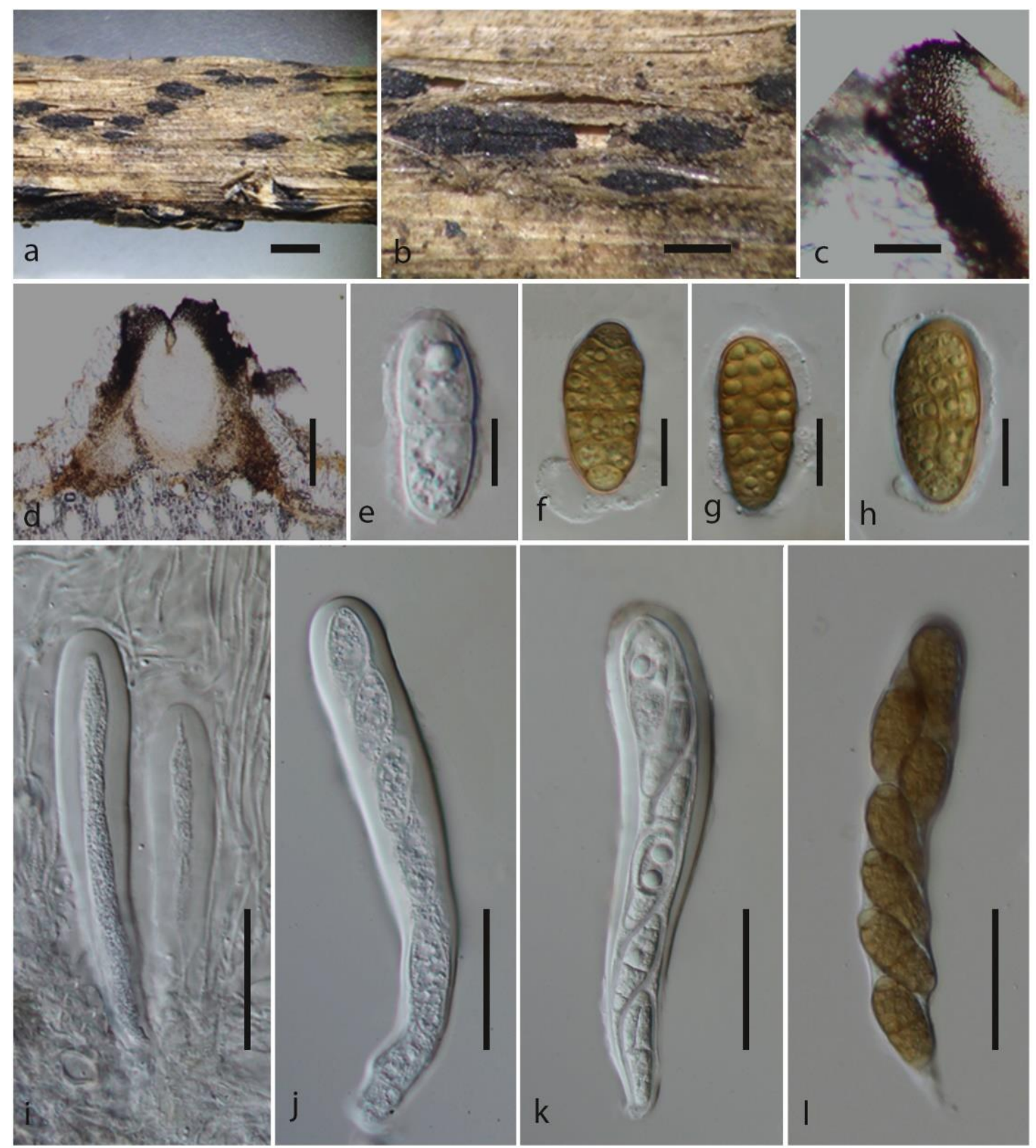

Figure 13 - Hysterographium fraxi. a, b Hysterothecia on host surface. c Peridium. d Hand section of hysterothecia. $\mathrm{e}-\mathrm{h}$ Ascospores i Immature asci with pseudoparaphyses. $\mathrm{j}-1$ Asci with ascospores. Scale bars: $\mathrm{a}=1 \mathrm{~mm}, \mathrm{~b}=500 \mu \mathrm{m}, \mathrm{c}=100 \mu \mathrm{m}, \mathrm{d}=300 \mu \mathrm{m}, \mathrm{e}=10 \mu \mathrm{m}, \mathrm{f}-\mathrm{h}=20 \mu \mathrm{m}, \mathrm{i}-\mathrm{j}=50 \mu \mathrm{m}$.

composed with cells of textura angularis. Hamathecium 1-1.5 $\mu \mathrm{m}$ wide, persistent, septate, massed, branched above the asci. Asci 120-130 $\times 18-22 \mu \mathrm{m},(\bar{x}=125 \times 20 \mu \mathrm{m}, \mathrm{n}=30), 8$-spored, bitunicate, cylindrical to clavate, with short, narrow pedicel. Ascospores $30-38 \times 12-15 \mu \mathrm{m}(\bar{x}=35$ $\times 14 \mu \mathrm{m}, \mathrm{n}=30$ ), uni-seriate to biseriate, asymmetric, hyaline to pale brown, muriform, septation highly variable, one prominent constricted longitudinal septa in the middle, guttulate, mucilaginous sheath present in both mature and immature spores. Asexual morph: Undetermined.

Material examined - RUSSIA, Rostov region, Rostov-on-Don City, Botanical Garden of Southern Federal University, secondary forest $(47.2315173 \mathrm{~N} ; 39.6600866 \mathrm{E})$, on dead branch of Fraxinus excelsior (Oleaceae), 15 April 2015, TS Bulgakov, T-198 (MFLU 15-1902; HKAS96321); Krasnodar region, Sochi City, Central city district, Sochi Dendrarium, collection of 
plants (43.5707N; 39.7438), 8 October 2014, dying leaves and twigs of Catalpa bignonioides (Bignoniaceae) TS Bulgakov, T-893 (MFLU 15-3035; HKAS96322); Rostov region, Krasnosulinsky District, Donskoye forestry, Kabanya Balka (Boar gully), ravine forest (47 $85^{\prime} 99^{\prime \prime}$ N; $40^{\circ} 25^{\prime} 24^{\prime \prime}$ E), 27 October 2015, dying and dead twigs of Fraxinus excelsior (Oleaceae), TS Bulgakov, T-1019 (MFLU 15-3681; HKAS96323)

Known distribution - Switzerland (Zogg, 1943) and from Canada (Lohman 1934).

Notes - Hysterographium is characterized by ovoid to ellipsoid-fusoid, relatively broad, pigmented dictyospores, with one to several longitudinal septa, usually constricted at the firstformed septum (Boehm et al. 2009a). Our isolate fits with the morphological description of $H y$. fraxi. In multigene phylogenetic analyses our strains (MFLU 15-1902, MFLU 15-3035 and MFLU 15-3681) clade to Hy. fraxi (CBS 109.43 and CBS 242.34) with high statistical support (Fig. 1: 99\% MLBS, $1.00 \mathrm{BPP}$ ). Hysterographium was belonged to Pleosporomycetidae genera incertae sedis (Goh et al. 1998, Boehm et al. 2009a), however in this study also we placed it as previous because this genus still have a species and less support in the multigene phylogeny.

Mytilinidiales E.W.A. Boehm, C.L. Schoch \& Spatafora, Mycol. Res. 113 (4): 468 (2009)

Notes - The genera Mytilinidion, Lophium and Quasiconcha formed a monophyletic clade, representing the order Mytilinidiales (Boehm et al. 2009b). The conchate nature of the hysterothecia and the thin-walled peridium are characteristic features of this group. (Boehm et al. 2009a, b, Hyde et al. 2013). Boonmee et al. (2012) introduced a new genus Halokirschsteiniothelia based on multigene phylogenetic analysis. Although characters of Halokirschsteiniothelia are unusual for this group and placement was tentative (Boonmee et al. 2012). In our multigene phylogenetic analysis also confirmed the placement of monotypic order Mytilinidiales within the class Dothideomycetes.

Mytilinidion didymospora Jayasiri, Camporesi \& K.D. Hyde, sp. nov.

Fig. 14

Index Fungorum number: IF554457; Facesoffungi number: FoF04584

Etymology: The epithet "didymospora" refers to the ascospores having two cells.

Holotype: MFLU 15-3252

Saprobic on dead cones of Cupressus glabra (Cupressaceae). Sexual morph: Hysterothecia 500-800 $\mu \mathrm{m}$ long $\times 101-135 \mu \mathrm{m}$ wide $\times 110-149 \mu \mathrm{m}$ high $(\bar{x}=700 \times 122 \times 129 \mu \mathrm{m}, \mathrm{n}=10)$, navicular, flexuous, superficial on host tissue, scattered or appear as a group, with a longitudinal slit, surface black and shiny. Peridium12-19 $\mu$ mwide $(\bar{x}=14 \mu \mathrm{m})$, carbonaceous, narrow, thickening equally, composed of cells of textura angularis. Hamathecium $1-1.5 \mu \mathrm{m}$ wide, persistent, septate, hyaline, branched, shorter than the asci. Asci 71-94 $\times 4-6 \mu \mathrm{m}(\bar{x}=84 \times 5 \mu \mathrm{m}, \mathrm{n}$ $=20), 8$-spored, bitunicate, cylindrical to clavate, with short, narrow pedicel. Ascospores $14-18 \times$ 2-4 $\mu \mathrm{m}(\bar{x}=15 \times 3 \mu \mathrm{m}, \mathrm{n}=20)$, uni-seriate to biseriate, asymmetric, cylindrical, one end tapering and another end rounded, hyaline to pale brown, 1-septate, not constricted at the septa, guttules present, mucilaginous sheath absent, smooth-walled. Asexual morph: Undetermined.

Culture characteristics - Colonies on MEA attaining 12-15 mm diam. after 7 days at $25{ }^{\circ} \mathrm{C}$, with irregular pale brown edge, brown, with dense aerial mycelium on the surface with brown, reverse similar.

Material examined - ITALY, Forlì-Cesena [FC] Province, Montebello - Modigliana, on dead land cones of Cupressus glabra (Cupressaceae), 6 October 2015, Erio Camporesi, IT 2629 (MFLU 15-3252, holotype; HKAS96319, isotype), ex-type living cultures MFUCC16-0619, BCC.

Notes - Mytilinidion didymospora is similar to other Mytilinidion species in having fragile yet persistent carbonaceous, bivalve shell-shaped ascomata, thin-walled, scleroparenchymatous peridium enclosing a hamathecium of narrow trabeculate pseudoparaphyses, borne in a gel matrix and transversely septate phragmospores. Mytilinidion didymospora groups with M. mytilinellum (EB 386) with 98\% MLBS/1.00 BPP statistical support. Mytilinidion mytilinellum has (2-)3(-5)septate, yellow ascospores, while My. didymospora has 1-septate, pale brown ascospores. In addition, My. mytilinellum is characterized by a longitudinal cristate-like apex and base edge 
attached with the substrate, whereas My. didymospora has aslightly connivant apical portion and base spread on the substrate. Therefore, My. didymospora is distinct from M. mytilinellum based on morphology and phylogeny. All recorded Mytilinidion species are from Pinaceae, Cupressaceae, and Taxodiaceae plant families (Lohman 1932, Zogg 1962, Speer 1986, Barr 1990a) and interestingly our isolate is also from the family Cupressaceae.

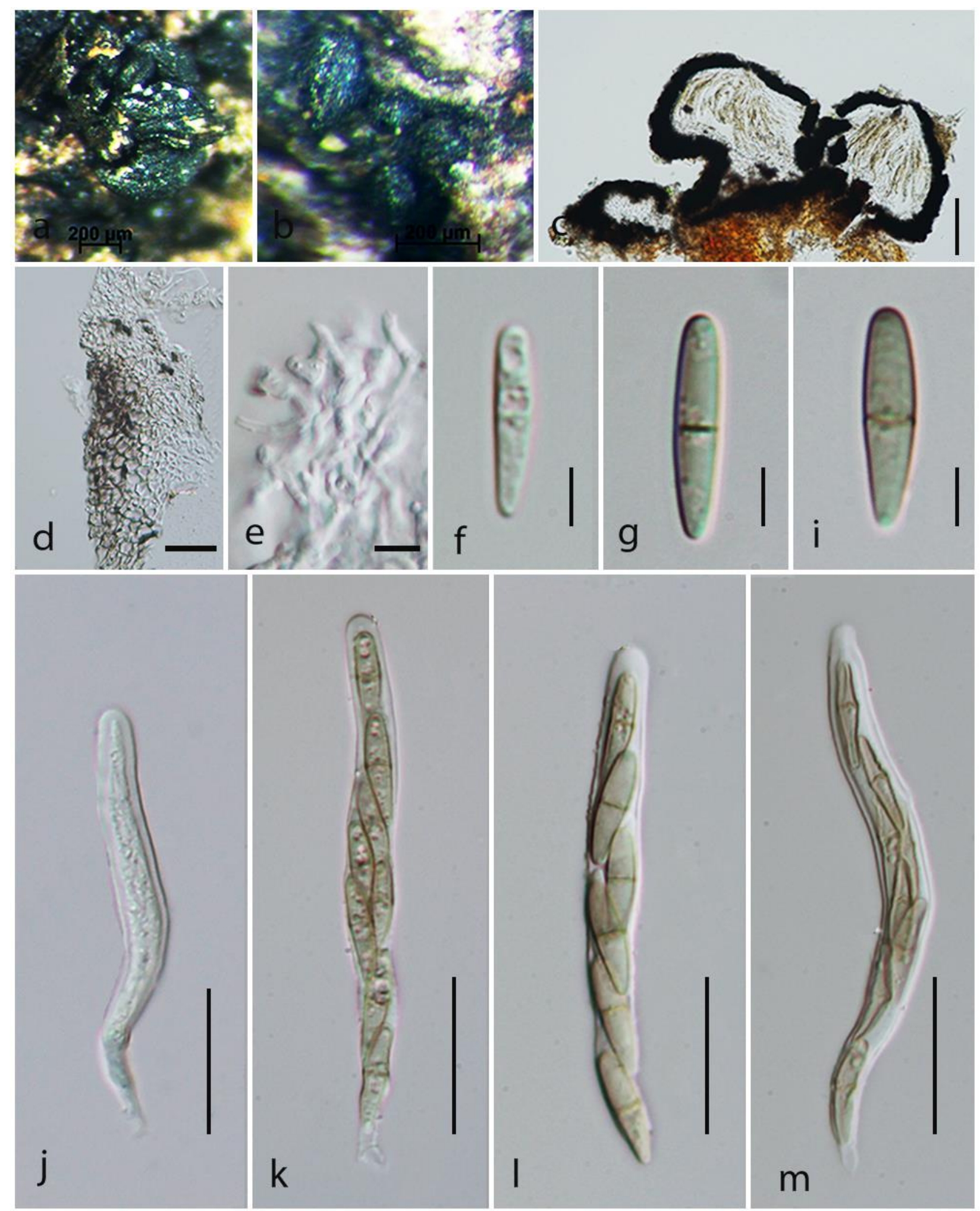

Figure 14 - Mytilinidion didymospora (holotype). a, b View of hysterothecia on host surface. c Section through hysterothecium. d Peridium. e Pseudoparaphyses. $f-i$ Ascospores. $\mathrm{j}-\mathrm{m}$ Asci. Scale bars: $\mathrm{c}=50 \mu \mathrm{m}, \mathrm{d}=20 \mu \mathrm{m}, \mathrm{e}=10 \mu \mathrm{m}, \mathrm{f}-\mathrm{i}=5 \mu \mathrm{m}, \mathrm{j}-\mathrm{m}=30 \mu \mathrm{m}$. 


\section{Discussion}

In this study on hysteriform Dothideomycetes, we introduce six new species based on morphological and phylogenetic data. Hysterobrevium hakeae, Hysterobrevium rosae, Hysterium doimaeensis, Hysterium thailandica, Mytilinidion didymospora and Purpurepithecium are illustrated and discussed. In addition, we propose Hysterium curtisii (Basionym) as the current name for Ostreichnion curtisii. The genus Ostreichnion comprised O. curtisii (CBS 198.34) and $O$. sassafras (CBS 322.34) introduced by Lohman (1934). Ostreichnion nova-caesariense is quite similar to $O$. sassafras, but no molecular data are available for comparison. However, the phylogenetic analysis shows that $O$. curtisii is distinct from the generic type, $O$. sassafras. These three species are morphologically similar, having mytilinidioid ascomata within Hysteriaceae, but differ with $O$. sassafras having ascospores with up to $27 \mathrm{septa}$, and four spored asci. Therefore, the family Hysteriaceae must also encompass some mytilinidioid forms (Boehm et al. 2009b) as observed in the genera Hysterium and Ostreichnion. In addition, new records of Hysterium angustatum, Gloniopsis subrugosa and Hysterographium fraxini are described and illustrated. Hysterium angustatum has been recorded from New Zealand, South Africa, North America (Boehm et al. 2009a) and Thailand (Hyde et al. 2016) but is reported here for the first time from Italy. Gloniopsis subrugosa has been reported from Argentina (Messuti \& Lorenzo 2003), Europe (Zogg 1962), North America (Barr 1990b), South Africa (van der Linde 1992) and from Thailand in this study.

The new family Acrogenosporaceae is introduced and placed in the order Minutisphaerales based on phylogenetic analyses and based on morphological differences with Minutisphaeraceae. Minutisphaera is characterized by a slit-like opening in the immature ascomata, which become apothecioid when mature (Raja et al. 2013, 2015), providing morphological support for the close relationship within the order. Acrogenosporaceae is typified by the genus Acrogenospora, which is the asexual morph of Farlowiella (hysterothecial sexual morph). We used this name, because Rossman et al. (2015) proposed the protection of Acrogenospora (1971) over Farlowiella (1891). Furthermore, this study supports the synonymy of Acrogenospora with Farlowiella.

We conducted a phylogenetic analysis of protein data (i.e. amino acid sequences) for whole hysteriform Dothideomycetes. Interestingly, the $R P B 2$ amino acid sequences resolved the relationships for this group, but additional sequences would be desirable for a more complete understanding. Among the 301 strains included in the nucleic acid phylogeny, $R P B 2$ gene sequence data were only available for 95 strains. Representing functionally important proteins and being unambiguously alignable across phylogenetically distinct taxa, amino acid sequence data are promising for resolving phylogenetic relationships at higher taxonomic levels.

\section{Acknowledgements}

Kevin D. Hyde would like to thank the Thailand Research Funds entitled Biodiversity, phylogeny and role of fungal endophytes on above parts of Rhizophora apiculata and Nypa fruticans (grant no: RSA5980068), The future of specialist fungi in a changing climate: baseline data for generalist and specialist fungi associated with ants, Rhododendron species and Dracaena species (grant no: DBG6080013), Impact of climate change on fungal diversity and biogeography in the Greater Mekong Subregion (grant no: RDG6130001) and Mae Fah Luang University for the grant "Biodiversity, phylogeny and role of fungal endophytes of Pandanaceae" (grant number: 592010200112), "Diseases of mangrove trees and maintenance of good forestry practice" (grant number: 60201000201) and Taxonomy diversity, Phylogeny and Evolution of fungi in Capnodiales (grant no: 666713) for supporting this study. This work was funded by the grants of the National Natural Science Foundation of China (NSFC Grants No. 31670027 \& 31460011). Subashini C. Jayasiri thanks Guizhou University for the help with molecular work and particularly grateful to Mr. T.S. Bulgakov from Academy of Biology and Biotechnology, Southern Federal University, Russia for sending the specimens, Dr. M. Doilom and Danushka Sandaruwan from Mae Fah Luang University, Thailand for helping to obtain sequence data. Gareth Jones thanks Alun Jones and Jonathan Batten for assistance in collecting in Australia. 


\section{References}

Ariyawansa HA, Hyde KD, Jayasiri SC, Buyck B et al. 2015 - Fungal diversity notes 111-252 taxonomic and phylogenetic contributions to fungal taxa. Fungal Diversity 75, 27-274.

Barr ME. 1987 - Prodromus to class Loculoascomycetes. Hamilton I. Newell, Inc., Amherst, Massachusetts: published by the author.

Barr ME. 1990a - Melanommatales (Loculoascomycetes). North American Flora, Series II, Part 13, $1-129$.

Barr ME. 1990b - Some dictyosporous genera and species of Pleosporales in North America. Memoirs of the New York Botanical Garden 62, 1-92.

Boehm EWA, Mugambi GK, Miller AN, Huhndorf SM et al. 2009a - A molecular phylogenetic reappraisal of the Hysteriaceae, Mytilinidiaceae and Gloniaceae (Pleosporomycetidae, Dothideomycetes) with keys to world species. Studies in Mycology 64, 49-83.

Boehm EWA, Schoch CL, Spatafora JW. 2009b - On the evolution of the Hysteriaceae and Mytilinidiaceae (Pleosporomycetidae, Dothideomycetes, Ascomycota) using four nuclear genes. Mycological Research 113, 461-479.

Boonmee S, Ko TWK, Chukeatirote E, Chen H et al. 2012 - Two new Kirschsteiniothelia species with Dendryphiopsis anamorphs cluster in Kirschsteiniotheliaceae fam. nov. Mycologia, 104, 698-714Boonmee S, D'souza MJ, Luo Z, Pinruan U et al. 2016 - Dictyosporiaceae fam. nov. Fungal Diversity 80, 457-482

Chomnunti P, Hongsanan S, Hudson BA, Tian Q et al. 2014 - The sooty moulds. Fungal Diversity $66,1-36$.

Clements FE, Shear CL. 1931 - The Genera of Fungi. HW Wilson Co. Publ., Minneapolis, MN, U.S.A.

de Almeida DAC, Gusmao LFP, Miller AN. 2014 - A new genus and three new species of hysteriaceous ascomycetes from the semiarid region of Brazil. Phytotaxa 176 (1), 298-308.

Doilom M, Dissanayake AJ, Wanasinghe DN, Boonmee S et al. 2017 - Microfungi on Tectona grandis (teak) in northern Thailand. Fungal Diversity 82, 107-182.

Ferrer A, Miller AN, Shearer CA. 2011 - Minutisphaera and Natipusilla: two new genera of freshwater Dothideomycetes. Mycologia 103, 411-423.

Gäumann EA. 1949 - Die Pilze, Grundzüge ihrer Entwicklungsgeschichte und Morphologie. Birkhäuser. Basel.

Goh TK, Hyde KD, Tsui KM. 1998 - The hyphomycete genus Acrogenospora, with two new species and two new combinations. Mycological Research 102, 1309-1315.

Huelsenbeck JP, Ronquist F. 2001 - MRBAYES: Bayesian inference of phylogenetic trees. Bioinformatics 17, 754-755.

Hyde KD, Hongsanan, S, JeewonR, Bhat DJ et al. 2016 - Fungal diversity notes 367-491: taxonomic and phylogenetic contributions to fungal taxa. Fungal Diversity 80, 1-270.

Hyde KD, Jones EBG, Liu JK, Ariyawansa HA et al. 2013 - Families of Dothideomycetes. Fungal Diversity 63, 1-313.

Hyde KD, Norphanphoun C, Abreu VP, Bazzicalupo A et al. 2017 - Fungal diversity notes 603708: taxonomic and phylogenetic notes on genera and species. Fungal Diversity 87(1), 1-235.

Hyde KD, Tennakoon DS, Norphanphoun C, Chaiwan N et al. 2018 - Mycosphere notes 225-280. Mycosphere (In press).

Index Fungorum. 2018 - Available from: http://www.indexfungorum.org/Names/Names.asp. (Accessed January 2018)

Jayasiri SC, Hyde KD, Ariyawansa HA, Bhat J et al. 2015 - The Faces of Fungi database: fungal names linked with morphology, phylogeny and human impacts. Fungal Diversity. 74 (1), 318

Jayasiri SC, Hyde KD, Jones EBG, Ariyawansa HA et al. 2017 - A new hysteriform Dothideomycete (Gloniaceae, Pleosporomycetidae Incertae sedis), Purpurepithecium murisporum gen. et sp. nov. on pine cone scales. Cryptogamie Mycologie 38, 241-251. 
Jayasiri SC, Jones EBG, Kang JC, Promputtha I et al. 2016 - A new species of genus Anteaglonium (Anteagloniaceae, Pleosporales) with its asexual morph. Phytotaxa 263 (3), 233-244.

Kirk PM, Cannon PF, David JC, Stalpers JA. 2001 - Ainsworth \& Bisby's dictionary of the fungi, 9th edn. CABI, Wallingford.

Kirk PM, Cannon PF, Minter DW, Stalpers JA. 2008 - Ainsworth \& Bisby's dictionary of the fungi, 10th edn. CABI, Wallingford.

Li GJ, Hyde KD, Zhao RL, Hongsanan S et al. 2016 - Fungal diversity notes 253-366: taxonomic and phylogenetic contributions to fungal taxa. Fungal diversity 78(1), 1-237.

Liew ECY, Aptroot A, Hyde KD. 2001 - Phylogenetic significance of the pseudoparaphyses in Loculoascomycete taxonomy. Molecular Phylogeny and Evolution 16, 392-402.

Lindau G. 1897 - Hysteriineae. In: Engler \& Prantl, Naturliche Pflanzenfamilien. I. Teil, I. Abteilung. 1, 265-278.

Liu JK, Hyde KD, Jones EBG, Ariyawansa HA et al. 2015 - Fungal diversity notes 1-110: taxonomic and phylogenetic contributions to fungal species. Fungal Diversity 72, 1-197.

Liu YJ, Whelen S, Hall BD. 1999 - Phylogenetic relationships among ascomycetes: evidence from an RNA polymerase II subunit. Molecular Biology and Evolution. 16, 1799-1808.

Lohman ML. 1932 - Three new species of Mytilidion in the proposed subgenus Lophiopsis. Mycologia 24, 477-484.

Lohman ML. 1934 - A cultural and taxonomic study of Hysterium hyalinum. Papers of the Michigan Academy of Science Arts \& Letters 19, 133-140.

Ludwig W, Strunk O, Westram R, Richter L et al. 2004 - ARB: a software environment for sequence data. Nucleic Acids Research 32, 1363-1371.

Lumbsch HT, Huhndorf SM. 2010 - Myconet volume 14 Part One. Outline of Ascomycota-2009. Fieldiana Life Earth Science 1, 1-922.

Luttrell ES. 1955 - The ascostromatic Ascomycetes. Mycologia 47, 511-532.

Messuti MI, Lorenzo LE. 2003 - Notes on the genus Hysterographium (Ascomycota, Hysteriaceae) in southern South America. Nova Hedwigia 76, 451-458.

Mugambi GK, Huhndorf SM. 2009 - Molecular phylogenetics of Pleosporales: Melanommataceae and Lophiostomataceae recircumscribed (Pleosporomycetidae, Dothideomycetes, Ascomycota). Studies in Mycology 64, 103-121.

Müller E, von Arx JA. 1950 - Einige Aspekte zur Systematik pseudosphärialer Ascomyceten. Berichte der Schweizerischen Botanischen Gesellschaft 60, 329-397.

Nylander JAA. 2004 - MrModeltest 2.0. Program distributed by the author. Evolutionary Biology Centre, Uppsala University.

Perera RH, Hyde KD, Peršoh D, Jones EBG et al. 2018 - Additions to wild seed and fruit fungi 1: The sexual morph of Diaporthe rosae on Magnolia champaca and Senna siamea fruits in Thailand. Mycosphere 9(2), 256-270.

Raja HA, El-Elimat T, Oberlies NH, Shearer CA et al. 2015 - Minutisphaerales (Dothideomycetes, Ascomycota): a new order of freshwater ascomycetes including a new family, Minutisphaeraceae, and two new species from North Carolina, USA. Mycologia 107(4), 84562.

Raja HA, Oberlies NH, Figueroa M, Tanaka K et al. 2013 - Freshwater ascomycetes: Minutisphaera (Dothideomycetes) revisited, including one new species from Japan. Mycologia 105, 959-976.

Rambaut A, Drummond A. 2008 - FigTree: Tree figure drawing tool, version 1.2. 2. Institute of Evolutionary Biology, University of Edinburgh.

Rannala B, Yang Z. 1996 - Probability distribution of molecular evolutionary trees: a new method of phylogenetic inference. Journal of Molecular Evolution 43(3), 304-311.

Rehner S. 2001 - Primers for Elongation Factor 1- $\alpha$ (EF1- $\alpha)$

Rossman AY, Crous PW, Hyde KD, Hawksworth DL et al. 2015 - Recommended names for pleomorphic genera in Dothideomycetes. IMA Fungus 6(2), 507-523. 
Schoch CL, Crous PW, Groenewald JZ, Boehm EW et al. 2009 - A class-wide phylogenetic assessment of Dothideomycetes. Studies in Mycology 64, 1-15.

Shearer CA, Miller AN, Nelson P, Tanaka K et al. 2009 - The molecular phylogeny of freshwater Dothideomycetes. Study in Mycology 145-153.

Simonis JL, Raja HA, Shearer CA. 2008 - Extracellular enzymes and soft rot decay: Are ascomycetes important degraders in freshwater? Fungal Diversity 31, 135-146.

Spatafora JW, Owensby AC, Douhan GW, Boehm EWA et al. 2012 - Phylogenetic placement of the ectomycorrhizal genus Cenococcum in Gloniaceae (Dothideomycetes). Mycologia 104(3), $758-765$.

Speer EO. 1986 - A propos de champignons du Brésil III. Mytilidion resinae sp. nov. (Hysteriales) et sa forme conidienne, Camaroglobulus resinae gen. et spec. nov. (Sphaeropsidales). Bulletin Trimestriel de la Société de Mycologie de France 102, 97-100.

Stamatakis A, Hoover P, Rougemont J. 2008 - A rapid bootstrap algorithm for the RAxML web servers. Systematic Biology 57, 758-771.

Suetrong S, Schoch CL, Spatafora JW, Kohlmeyer B et al. 2009 - Molecular systematics of the marine Dothideomycetes. Study in Mycology 64, 155-173.

Sung GH, Sung JM, Hywel-Jones NL, Spatafora JW. 2007 - A multi-gene phylogeny of Clavicipitaceae (Ascomycota, Fungi): identification of localized incongruence using a combinational bootstrap approach. Molecular Phylogenetics and Evolution 44, 1204-1223.

Thambugala KM, Hyde KD, Eungwanichayapant PD, Romero AI et al. 2016 - Additions to the Genus Rhytidhysteron in Hysteriaceae. Cryptogamie, Mycologie 37, 99-116.

Thambugala KH, Peršoh D, Perera, RH, Hyde KD. 2018 - The genus Pseudodidymosphaeria. Asian Journal of Mycology (in prep).

Tibpromma S, Hyde KD, Jeewon R, Maharachchikumbura SSN et al. 2017 - Fungal diversity notes 491-602: taxonomic and phylogenetic contributions to fungal taxa. Fungal Diversity 83, 1261.

van der Linde EJ. 1992 - Notes on the South African Hysteriaceae (Ascomyctes: Mycotina). South African Journal of Botany 58, 491-499.

Vilgalys R, Hester M. 1990 - Rapid genetic identification and mapping of enzymatically amplified ribosomal DNA from several Cryptococcus species. Journal of Bacteriology 172, 4238-4246.

Voglmayr H, Fournier J, Jaklitsch WM. 2017 - Stigmatodiscus pruni, a new dothideomycete with hysteriform ascomata. Sydowia 69, 29-35.

von Arx JA, Müller E. 1975 - A re-evaluation of the bitunicate Ascomycetes with keys to families and genera. Studies in Mycology Baarn 9, 1-159.

Wanasinghe DN, Phukhamsakda C, Hyde KD, Jeewon R et al. 2018 - Fungal diversity notes 709839: taxonomic and phylogenetic contributions to fungal taxa with an emphasis on fungi on Rosaceae. Fungal Diversity 89(1), 1-236.

White TJ, Bruns T, Lee S, Taylor JW. 1990 - Amplification and direct sequencing of fungal ribosomal RNA genes for phylogenetics. In: Innis MA, Gelfand DH, Sninsky JJ, White TJ (eds) PCR protocols: A guide to methods and applications. Academic, New York, 315-322.

Wijayawardene NN, Hyde KD, Lumbsch HT, Liu JK et al. 2018 - Outline of Ascomycota: 2017. Fungal Diversity 88(1), 167-263.

$\mathrm{Xu}$ Y, Mafezoli J, Oliverira MCF, U'ren JM et al. 2015 - Anteaglonialides A-F and Palmarumycins CE1-CE3 from Anteaglonium sp. FL0768, a fungal endophyte of the spike moss Selaginella arenicola. Journal of Natural Product 78, 2738-2747.

Zhaxybayeva O, Gogarten JP. 2002 - Bootstrap, Bayesian probability and maximum likelihood mapping: exploring new tools for comparative genome analyses. BMC Genomics 3, 4.

Zogg H. 1962 - Die Hysteriaceae s. str. und Lophiaceae, unter besonderer Berücksichtigung der mitteleuropäischen Formen. Beiträge zur Kryptogamenflora der Schweiz, Band 11, 1-190. 
Appendix 1 GenBank accession numbers used in this study. GenBank accessions marked in bold represent new sequences generated in the current study.

\begin{tabular}{|c|c|c|c|c|c|}
\hline Species name & Strain & LSU & SSU & TEF & RPB2 \\
\hline $\begin{array}{l}\text { Acanthostigma } \\
\text { perpusillum }\end{array}$ & UAMH 7237 & AY856892 & AY856937 & & \\
\hline Acrocordia subglobosa & HTL940 & JN887392 & JN887373 & & \\
\hline $\begin{array}{l}\text { Acrogenospora } \\
\text { sphaerocephala }\end{array}$ & CBS 16476 & GU301791 & GU296129 & GU349059 & GU371748 \\
\hline $\begin{array}{l}\text { Acrogenospora } \\
\text { sphaerocephala }\end{array}$ & CBS 206.36 & AY541492 & AY541482 & DQ677931 & DQ677989 \\
\hline $\begin{array}{l}\text { Acrogenospora } \\
\text { sphaerocephala }\end{array}$ & CBS 17973 & & GU296148 & & \\
\hline $\begin{array}{l}\text { Acrogenospora } \\
\text { sphaerocephala }\end{array}$ & $J X-43$ & KF836062.1 & KF836061 & & \\
\hline $\begin{array}{l}\text { Acrogenospora } \\
\text { sphaerocephala }\end{array}$ & FMR11021 & HF677191.1 & & & \\
\hline $\begin{array}{l}\text { Acrogenospora } \\
\text { sphaerocephala }\end{array}$ & MFLUCC:16-0179 & MH606222 & & & MH626448 \\
\hline $\begin{array}{l}\text { Acrogenospora } \\
\text { thailandica }\end{array}$ & MFLUCC 17-2396 & MH606223 & MH606221 & & MH626449 \\
\hline Acrospermum adeanum & M133 & EU940104 & EU940256 & & EU940320 \\
\hline $\begin{array}{l}\text { Acrospermum } \\
\text { compressum }\end{array}$ & M151 & EU940084 & EU940012 & & EU940301 \\
\hline Acrospermum gramineum & M152 & EU940085 & EU940013 & & EU940302 \\
\hline Aglaospora profusa & CBS 123109 & GU301792 & GU296130 & GU349062 & \\
\hline Aigialus grandis & $2 \mathrm{Q}$ & GU301794 & GU296132 & GU349063 & \\
\hline $\begin{array}{l}\text { Aliquandostipite } \\
\text { khaoyaiensis }\end{array}$ & CBS 118232 & GU301796 & NG 016494 & & \\
\hline Alternaria alternata & AFTOL ID 1610 & DQ678082 & DQ678031 & DQ677927 & DQ677980 \\
\hline Amniculicola parva & CBS 123092 & FJ795497 & GU296134 & GU349065 & \\
\hline Anisomeridium ubianum & MPN94 & GU327709 & GU327682 & & \\
\hline $\begin{array}{l}\text { Anteaglonium } \\
\text { abbreviatum }\end{array}$ & ANM925a/GKM129 & GQ221877 & & GQ221915 & \\
\hline Anteaglonium globosum & SMH5283 & GQ221911 & & GQ221919 & \\
\hline Anteaglonium parvulum & SMH5210 & GQ221907 & & GQ221917 & \\
\hline Arthopyrenia cinchonae & Lu29583 & JN872351 & & & \\
\hline Arthopyrenia cinchonae & MPN417 & KM453759 & & & \\
\hline Arthopyrenia salicis & CBS 36894 & AY538339 & AY538333 & KF443404 & KF443397 \\
\hline Arthrographis longispora & UTHSC 053220 & HG004540 & & & \\
\hline Asterina phenacis & TH 589 & GU586217 & GU586211 & & \\
\hline Asterina weinmanniae & TH 592 & GU586218 & GU586212 & & \\
\hline Asterodiscus tamaricis & L114 & & & KU234133 & KU234116 \\
\hline $\begin{array}{l}\text { Asterotexis } \\
\text { cucurbitacearum }\end{array}$ & PMA M 0141224 & HQ610510 & & & \\
\hline $\begin{array}{l}\text { Asterotexis } \\
\text { cucurbitacearum }\end{array}$ & VIC 42814 & KP143734 & & & \\
\hline $\begin{array}{l}\text { Astrosphaeriella } \\
\text { bakeriana }\end{array}$ & CBS 115556 & GU301801 & & GU349015 & \\
\hline Astrothelium variolosum & MPN43 & KM453768 & & & \\
\hline Aureobasidium pullulans & CBS 58475 & DQ470956 & DQ471004 & DQ471075 & DQ470906 \\
\hline
\end{tabular}


Appendix 1 Continued.

\begin{tabular}{|c|c|c|c|c|c|}
\hline Species name & Strain & LSU & SSU & TEF & RPB2 \\
\hline Bambusaria bambusae & MFLUCC 12-0851 & KP687812 & & KP687982 & KP687890 \\
\hline Bambusaria bambusae & CBS 139763 & KP687813 & & KP687983 & KP687891 \\
\hline Bathelium feei & MPN397 & KM453773 & & & \\
\hline Beverwykella pulmonaria & CBS 28353 & GU301804 & KY190005 & & GU371768 \\
\hline Bimuria novae zelandiae & AFTOL-ID 931 & AY016356 & AY016338 & DQ471087 & DQ470917 \\
\hline $\begin{array}{l}\text { Boeremia exigua var. } \\
\text { exigua }\end{array}$ & CBS 43174 & EU754183 & NG 016533 & KY484687 & KT389569 \\
\hline Botryosphaeria dothidea & AFTOL ID 946 & DQ678051 & & DQ767637 & DQ677944 \\
\hline Capnobotryella renispora & CBS 21490 & GU214398 & EF137360 & & \\
\hline Capnodium coffeae & CBS 14752 & DQ247800 & DQ247808 & DQ471089 & DQ247788 \\
\hline Catenulostroma abietis & CBS 45993 & DQ678092 & DQ678040 & DQ677933 & \\
\hline Cenococcum geophilum & HUNT A1 & & L76616 & & \\
\hline Cenococcum geophilum & CGMONT & & L76617 & & \\
\hline Cenococcum geophilum & CG54 & & JX093574 & & \\
\hline Cercospora beticola & CBS 116456 & DQ678091 & DQ678039 & & \\
\hline $\begin{array}{l}\text { Chaetothyriothecium } \\
\text { elegans }\end{array}$ & CPC 21375 & KF268420 & GU371734 & & \\
\hline $\begin{array}{l}\text { Cladosporium } \\
\text { cladosporioides }\end{array}$ & CBS 17054 & DQ678057 & DQ678004 & DQ677898 & DQ677952 \\
\hline Clavatispora thailandica & MFLUCC100107 & KF770458 & KF770457 & KF770459 & \\
\hline Coleroa robertiani & CBS 45864 & JQ036231 & & & \\
\hline $\begin{array}{l}\text { Collemopsidium } \mathrm{cf} . \\
\text { foveolatum }\end{array}$ & $\mathrm{RO} 27$ & KU556973 & KU556967 & KU556866 & \\
\hline $\begin{array}{l}\text { Collemopsidium cf. } \\
\text { ostrearum }\end{array}$ & s1473 & KU556976 & KU556971 & & \\
\hline Collemopsidium pelvetiae & $\mathrm{RO} 25$ & KU556868 & KU556965 & & KU556861 \\
\hline Collemopsidium sp. & $\mathrm{RO} 28$ & KU556974 & KU556968 & & KU556863 \\
\hline Corynespora cassiicola & CBS 100822 & GU301808 & NG 016518 & GU349052 & GU371742 \\
\hline Corynespora smithii & CABI 5649b & GU323201 & & GU349018 & GU371783 \\
\hline Delitschia didyma & UME 31411 & DQ384090 & AF242264 & & \\
\hline Delitschia winteri & AFTOL ID 1599 & DQ678077 & DQ678026 & DQ677922 & DQ677975 \\
\hline Didymella exigua & CBS 18355 & EU754155 & GU296147 & KR184187 & GU37176 \\
\hline Dissoconium aciculare & CBS 20489 & GU214419 & GU214523 & & \\
\hline Dothidea hippophaeos & CBS 188.58 & DQ678048 & U42475 & DQ677887 & DQ677942 \\
\hline Dothidea insculpta & CBS 18958 & DQ247802 & DQ247810 & DQ471081 & AF107800 \\
\hline Dothiorella sarmentorum & CBS 115038 & DQ377860 & KF766248 & & \\
\hline $\begin{array}{l}\text { Dyfrolomyces } \\
\text { tiomanensis }\end{array}$ & NTOU3636 & KC692156 & KC692155 & KC692157 & \\
\hline Elsinoe centrolobi & CBS 22250 & DQ678094 & DQ678041 & DQ677934 & \\
\hline Elsinoe phaseoli & CBS 16531 & DQ678095 & DQ678042 & DQ677935 & \\
\hline Elsinoe veneta & CBS 150.27 & DQ767658 & DQ767651 & DQ767641 & \\
\hline Entodesmium rude & CBS 65086 & GU301812 & & GU349012 & \\
\hline Eremodothis angulata & CBS 61074 & DQ384105 & DQ384067 & GU371821 & \\
\hline Eremomyces bilateralis & CBS 78170 & HG004545 & & & \\
\hline Extremus antarcticus & CCFEE 5312 & KF310020 & & & KF310086 \\
\hline Falciformispora lignatilis & BCC 21118 & GU371827 & GU371835 & GU371820 & \\
\hline
\end{tabular}


Appendix 1 Continued.

\begin{tabular}{|c|c|c|c|c|c|}
\hline Species name & Strain & LSU & SSU & TEF & RPB2 \\
\hline $\begin{array}{l}\text { Flavobathelium } \\
\text { epiphyllum }\end{array}$ & MPN67 & GU327717 & JN887382 & JN887423 & \\
\hline Floricola striata & JK 5678I & GU301813 & GU296149 & GU479852 & GU371758 \\
\hline Fusicladium africanum & CPC 12828 & EU035423 & & & \\
\hline Gibbera conferta & CBS 19153 & GU301814 & GU296150 & GU349041 & \\
\hline Gloniopsis arciformis & GKM L166A & GU323211 & GU323180 & & \\
\hline Gloniopsis kenyensis & GKM1010 & GQ221891 & & & \\
\hline Gloniopsis praelonga & CBS 112415 & FJ161173 & FJ161134 & FJ161090 & FJ161113 \\
\hline Gloniopsis praelonga & CMW 19983 & FJ161193 & FJ161152 & & \\
\hline Gloniopsis praelonga & CBS 123337 & FJ161195 & & & \\
\hline Gloniopsis praelonga & CMW 18053 & FJ161191 & FJ161150 & & \\
\hline Gloniopsis praelonga & SMH5280 & GQ221912 & & GQ221914 & \\
\hline Gloniopsis sp. & MFLUCC14 0581 & & & & \\
\hline Gloniopsis subrugosa & CBS 123346 & FJ161210 & & & \\
\hline Gloniopsis subrugosa & MFUCC 141179 & MH535892 & MH535884 & & MH535874 \\
\hline Gloniopsis subrugosa & SMH557 & GQ221896 & & & \\
\hline Glonium circumserpens & $\begin{array}{l}\text { CBS 123342/EB } \\
0332\end{array}$ & FJ161208 & FJ161160 & & \\
\hline Glonium circumserpens & $\begin{array}{l}\text { CBS 123343/EB } \\
0331\end{array}$ & FJ161200 & FJ161168 & FJ161108 & FJ161126 \\
\hline Glonium stellatum & CBS 20734 & FJ161179 & & & \\
\hline Glonium stellatum & ANM32 & GQ221887 & & GQ221926 & \\
\hline $\begin{array}{l}\text { Gonatophragmium } \\
\text { triuniae }\end{array}$ & CBS 138901 & KР004479 & & & \\
\hline $\begin{array}{l}\text { Graphyllium } \\
\text { caracolinensis }\end{array}$ & HUEFS 42838 & KF914914 & & & \\
\hline Heleiosa barbatula & JK 5548I & GU479787 & GU479753 & & \\
\hline Helicomyces roseus & AFTOL ID 1613 & DQ678083 & DQ678032 & DQ677928 & DQ677981 \\
\hline Hysterium angustatum & GKM5211 & GQ221906 & & & \\
\hline Hysterium angustatum & CMW 20409 & FJ161194 & FJ161153 & & \\
\hline Hysterium angustatum & SMH5216 & GQ221908 & & GQ221933 & \\
\hline Hysterium angustatum & GKM243a & GQ221899 & & GQ221928 & \\
\hline Hysterium angustatum & CBS 123334 & FJ161207 & & & \\
\hline Hysterium angustatum & CBS 23634 & FJ161180 & GU397359 & FJ161096 & FJ161117 \\
\hline Hysterium angustatum & MFLUCC 160623 & MH535893 & MH535885 & MH535878 & MH535875 \\
\hline Hysterium barrianum & ANM1495 & GQ221885 & & GQ221931 & \\
\hline Hysterium barrianum & ANM1442 & GQ221884 & & & \\
\hline Hysterium doimaeensis & MFLUCC 160338 & MH535894 & MH535886 & & \\
\hline Hysterium hyalinum & CBS 23734 & FJ161181 & FJ161141 & & \\
\hline Hysterium pulicare & ANM85 & GQ221898 & & GQ221934 & \\
\hline Hysterium pulicare & ANM1455 & GQ221904 & & GQ221932 & \\
\hline Hysterium thailandica & MFLUCC 16-0338 & MH535895 & & & MH535876 \\
\hline Hysterium vermiforme & GKM1234 & GQ221897 & & GQ221929 & \\
\hline $\begin{array}{l}\text { Hysterobrevium } \\
\text { constrictum }\end{array}$ & SMH5211 1 & GQ221905 & & GQ221923 & \\
\hline
\end{tabular}


Appendix 1 Continued.

\begin{tabular}{|c|c|c|c|c|c|}
\hline Species name & Strain & LSU & SSU & TEF & RPB2 \\
\hline $\begin{array}{l}\text { Hysterobrevium } \\
\text { constrictum }\end{array}$ & GKM426N & GQ221901 & & GQ221913 & \\
\hline Hysterobrevium hakeae & MFLU 162987 & MH535896 & & & \\
\hline Hysterobrevium mori & SMH 5273 & GU301820 & & & \\
\hline Hysterobrevium mori & GKM1214 & GQ221895 & & & \\
\hline Hysterobrevium mori & SMH 5286 & GU397345 & & & \\
\hline Hysterobrevium mori & SMH5273 & GQ221910 & & GQ221936 & \\
\hline Hysterobrevium mori & CBS 123564 & FJ161198 & & & \\
\hline Hysterobrevium mori & CBS 123336 & FJ161204 & NG 016534 & & \\
\hline Hysterobrevium mori & CBS 123563 & FJ161196 & & & \\
\hline Hysterobrevium mori & CBS 123335 & FJ161202 & & & \\
\hline Hysterobrevium mori & GKM 1013 & GU397344 & & GU397338 & \\
\hline Hysterobrevium rosae & MFUCC 14-0551 & MH535897 & & MH535879 & \\
\hline Hysterobrevium rosae & MFUCC 14-0552 & MH535898 & MH535887 & MH535880 & \\
\hline Hysterobrevium smilacis & CBS 20034 & FJ161177 & FJ161138 & & \\
\hline Hysterobrevium smilacis & CBS 114601 & FJ161174 & FJ161135 & FJ161091 & FJ161114 \\
\hline $\begin{array}{l}\text { Hysterodifractum } \\
\text { partisporum }\end{array}$ & HUEFS 42865 & KF914916 & & & \\
\hline $\begin{array}{l}\text { Hysterographium } \\
\text { flexuosum }\end{array}$ & GKM1262c & GQ221886 & & GQ221935 & \\
\hline Hysterographium fraxini & CBS 24234 & FJ161189 & & & \\
\hline Hysterographium fraxini & CBS 10943 & FJ161171 & FJ161132 & FJ161088 & \\
\hline Hysterographium fraxini & MFLU 15-1902 & MH535899 & MH535888 & MH535881 & \\
\hline Hysterographium fraxini & MFLU 15-3035 & MH535900 & MH535889 & MH535882 & \\
\hline Hysterographium fraxini & MFLU 15-3681 & MH535901 & MH535890 & MH535883 & \\
\hline Hysteropatella clavispora & AFTOL-ID 1305 & AY541493 & DQ678006 & DQ677901 & DQ677955 \\
\hline Hysteropatella elliptica & CBS 935.97 & DQ767657 & EF495114 & DQ767640 & DQ767647 \\
\hline Jahnula aquatica & R68 1 & EF175655 & EF175633 & & \\
\hline Jahnula bipileata & F49 1 & EF175657 & EF175635 & & \\
\hline Julella avicenniae & BCC 18422 & GU371823 & GU371831 & GU371816 & GU371787 \\
\hline Julella avicenniae & BCC 20173 & GU371822 & GU371830 & GU371815 & GU371786 \\
\hline Keissleriella cladophila & CBS 10455 & JX681090 & GU296155 & GU349043 & GU371735 \\
\hline $\begin{array}{l}\text { Kirschsteiniothelia } \\
\text { elaterascus }\end{array}$ & HKUCC7769 & AY787934 & & & \\
\hline Laurera megasperma & AFTOL ID 2094 & FJ267702 & & & \\
\hline Lentithecium fluviatile & CBS 122367 & GU301825 & GU296158 & GU349074 & \\
\hline Leptosphaeria biglobosa & CBS 30351 & GU301826 & & GU349010 & \\
\hline Leptosphaeria doliolum & CBS 50575 & GQ387576 & GQ387515 & GU349069 & KY064035 \\
\hline Leptoxyphium fumago & CBS 12326 & GU301831 & GU214535 & GU349051 & GU371741 \\
\hline Lichenothelia calcarea & L1324 & KC015062 & KC015082 & & \\
\hline Lichenothelia convexa & L1607 & KC015069 & KC015084 & & \\
\hline $\begin{array}{l}\text { Lindgomyces } \\
\text { breviappendiculatus }\end{array}$ & KT 1215 & AB521748 & AB521733 & & \\
\hline Lindgomyces ingoldianus & ATCC 200398 & AB521736 & NG 016531 & & \\
\hline Lophiostoma crenatum & AFTOL ID 1581 & & & DQ677912 & DQ677965 \\
\hline
\end{tabular}


Appendix 1 Continued.

\begin{tabular}{|c|c|c|c|c|c|}
\hline Species name & Strain & LSU & SSU & TEF & RPB2 \\
\hline Lophiostoma fuckelii & GKM 1063 & GU385192 & & GU327759 & \\
\hline $\begin{array}{l}\text { Lophiotrema } \\
\text { neoarundinaria }\end{array}$ & KT 856 & AB524596 & AB524455 & AB539109 & AB539096 \\
\hline Lophiotrema nucula & CBS 62786 & FJ795446 & FJ795489 & LC194410 & LC194465 \\
\hline Lophium elegans & EB 0366 & GU323210 & GU323184 & & \\
\hline Lophium mytilinum & CBS 114111 & & EF596818 & & \\
\hline Lophium mytilinum & AFTOL ID 1609 & DQ678081 & DQ678030 & DQ677926 & DQ677979 \\
\hline Lophium mytilinum & CBS 123344 & FJ161203 & & & \\
\hline Lophium mytilinum & CBS 26934 & DQ678081 & DQ678030 & DQ677926 & DQ677979 \\
\hline $\begin{array}{l}\text { Manglicola } \\
\text { guatemalensis }\end{array}$ & BCC20079 & FJ743449 & FJ743443 & & \\
\hline $\begin{array}{l}\text { Manglicola } \\
\text { guatemalensis }\end{array}$ & BCC20156 & FJ743448 & FJ743442 & & \\
\hline Massaria anomia & CBS 59178 & GU301839 & GU296169 & & GU371769 \\
\hline Massarina eburnea & CBS 47364 & FJ201983 & GU296170 & GU349040 & GU371732 \\
\hline Massarina igniaria & CBS 84596 & GU301841 & GU29617 & & GU371793 \\
\hline $\begin{array}{l}\text { Massariosphaeria } \\
\text { grandispora }\end{array}$ & CBS 61386 & GU301842 & GU296172 & GU349036 & GU371725 \\
\hline $\begin{array}{l}\text { Massariosphaeria } \\
\text { phaeospora }\end{array}$ & CBS 61186 & GU301843 & GU296173 & & GU371794 \\
\hline Megalotremis verrucosa & MPN104 & GU327718 & GU327694 & & \\
\hline Melanomma rhododendri & ANM 73 & GU385198 & & & \\
\hline $\begin{array}{l}\text { Microthyrium } \\
\text { microscopicum }\end{array}$ & CBS 115976 & GU301846 & GU296175 & & GU371734 \\
\hline Minutisphaera aspera & G427 1a & KP309993 & KP309999 & & \\
\hline Minutisphaera aspera & G427-1a & KP309993 & KP309999 & & \\
\hline $\begin{array}{l}\text { Minutisphaera } \\
\text { fimbriatispora }\end{array}$ & L A242 8A & HM196367 & HM196374 & & \\
\hline Minutisphaera japonica & JCM 18560 & AB733440 & AB733434 & & \\
\hline Montagnula opulenta & AFTOL ID 1734 & DQ678086 & & & DQ677984 \\
\hline $\begin{array}{l}\text { Morosphaeria } \\
\text { ramunculicola }\end{array}$ & KH 220 & AB807554 & AB797264 & AB808530 & \\
\hline Munkovalsaria rubra & IFRD 2017 & FJ795507 & GU456308 & & \\
\hline $\begin{array}{l}\text { Mycomicrothelia } \\
\text { miculiformis }\end{array}$ & $101 \mathrm{~B}$ & GU327720 & GU327696 & & \\
\hline Myriangium duriaei & CBS 26036 & DQ678059 & AY016347 & DQ677900 & DQ677954 \\
\hline Myriangium hispanicum & CBS 24733 & GU301854 & GU296180 & GU349055 & GU371744 \\
\hline Myrmaecium rubricosum & CBS 139067 & KP687881 & KP687977 & KР688049 & KP687955 \\
\hline Mytilinidion acicola & EB 0349 & GU323209 & GU323185 & & GU371757 \\
\hline Mytilinidion acicola & EB 0379 & GU397346 & GU397362 & & GU397355 \\
\hline Mytilinidion andinense & CBS 123562 & FJ161199 & & & \\
\hline Mytilinidion andinense & EB 0330 & FJ161199 & FJ161159 & FJ161107 & FJ161125 \\
\hline Mytilinidion australe & CBS 30134 & FJ161183 & & & \\
\hline Mytilinidion californicum & EB 0385 & GU323208 & GU323186 & & \\
\hline $\begin{array}{l}\text { Mytilinidion } \\
\text { didymospora }\end{array}$ & MFUCC16-0619 & MH535902 & MH535891 & & MH535877 \\
\hline
\end{tabular}


Appendix 1 Continued.

\begin{tabular}{|c|c|c|c|c|c|}
\hline Species name & Strain & LSU & SSU & TEF & RPB2 \\
\hline Mytilinidion mytilinellum & CBS 30334 & FJ161184 & FJ161144 & FJ161100 & FJ161119 \\
\hline Mytilinidion mytilinellum & EB 0386 & GU397347 & GU397363 & & GU397356 \\
\hline Mytilinidion resinicola & CBS 30434 & FJ161185 & NG 016511 & FJ161101 & FJ161120 \\
\hline Mytilinidion rhenanum & EB 0341 & GU323207 & GU323187 & & \\
\hline Mytilinidion rhenanum & CBS 13545 & FJ161175 & & & \\
\hline $\begin{array}{l}\text { Mytilinidion } \\
\text { scolecosporum }\end{array}$ & CBS 30534 & FJ161186 & NG 016510 & FJ161102 & FJ161121 \\
\hline Mytilinidion thujarum & EB 0268 & GU323206 & GU323188 & & \\
\hline Mytilinidion tortile & CBS 306.34 & FJ161187 & FJ161147 & & \\
\hline Natipusilla limonensis & L AF286 & HM196370 & HM196377 & & \\
\hline Natipusilla naponensis & L AF217 & HM196372 & HM196378 & & \\
\hline Neodevriesia hilliana & CBS 123187 & GU214414 & & & \\
\hline $\begin{array}{l}\text { Neomicrothyrium } \\
\text { siamense }\end{array}$ & IFRDCC 2194 & JQ036228 & JQ036223 & & \\
\hline Oedohysterium insidens & ANM1443 & GQ221882 & & & \\
\hline Oedohysterium insidens & CBS 23834 & FJ161182 & NG 016512 & FJ161097 & FJ161118 \\
\hline Oedohysterium sinense & CBS 123345 & FJ161209 & NG016513 & & \\
\hline Oedohysterium sinense & EB 0339 & GU397348 & GU397364 & GU397339 & GU397357 \\
\hline $\begin{array}{l}\text { Ostreichnion } \\
\text { centramurum }\end{array}$ & isolate chuni 70 & KM272256 & KM272257 & KM277819 & \\
\hline Ostreichnion curtisii & CBS 19834 & FJ161176 & FJ161137 & FJ161093 & \\
\hline Ostreichnion sassafras & CBS 32234 & FJ161188 & FJ161148 & & FJ161122 \\
\hline Otthia spiraeae & CBS 114124 & EF204498 & EF204515 & & EF204485 \\
\hline Patellaria atrata & CBS 95897 & GU301855 & GU296181 & GU349038 & GU371726 \\
\hline Petrophila incerta & CBS 118608 & GU323961 & GU323991 & & \\
\hline Phaeosphaeria avenaria & AFTOL ID 280 & AY544684 & AY544725. & DQ677885 & DQ677941 \\
\hline $\begin{array}{l}\text { Phaeothecoidiella } \\
\text { illinoisensis }\end{array}$ & CBS125223 & GU117901 & & & \\
\hline Phaeotrichum benjaminii & AFTOL ID 1184 & AY004340 & AY016348 & DQ677892 & DQ677946 \\
\hline $\begin{array}{l}\text { Phyllobathelium } \\
\text { anomalum }\end{array}$ & 242 & GU327722 & JN887386 & & \\
\hline Piedraia hortae & CBS 48064 & KF901943 & AY016349 & & KF902289 \\
\hline Piedraia quintanilhae & CBS 32763 & GU214468 & & & \\
\hline Pleospora herbarum & $\begin{array}{l}\text { CBS } 191 \\
\text { 86/AFTOL-ID } 940\end{array}$ & GU238232 & DQ247812 & DQ471090 & DQ247794 \\
\hline Pleosporales sp. & CLS 2009a & GQ289828 & & & GU371759 \\
\hline $\begin{array}{l}\text { Pleurotrema } \\
\text { thamplaensis }\end{array}$ & MFLUCC 150635 & KX925435 & KX925436 & & \\
\hline Polyplosphaeria fusca & KT 1616 & AB524604 & AB524463 & AB524820 & \\
\hline Preussia terricola & AFTOL ID 282 & AY544686 & AY544726 & DQ471063 & DQ470895 \\
\hline $\begin{array}{l}\text { Pseudorobillarda } \\
\text { eucalypti }\end{array}$ & MFLUCC 12-0422 & KF827457 & KF827463 & & KF827496 \\
\hline $\begin{array}{l}\text { Pseudorobillarda } \\
\text { phragmitis }\end{array}$ & CBS 39861 & EU754203 & EU754104 & & \\
\hline $\begin{array}{l}\text { Pseudorobillarda } \\
\text { siamensis }\end{array}$ & NTCL082-3 & KF827454 & KF827460 & KF827481 & KF827493 \\
\hline
\end{tabular}


Appendix 1 Continued.

\begin{tabular}{|c|c|c|c|c|c|}
\hline Species name & Strain & LSU & SSU & TEF & RPB2 \\
\hline Pseudorobillarda sp. & MFLUCC12 0316 & KF827453 & KF827459 & KF827480 & KF827492 \\
\hline Pseudorobillarda $\mathrm{sp}$. & MFLUCC12 0422 & KF827457 & KF827463 & KF827484 & KF827496 \\
\hline Pseudorobillarda texana & BCC12535 & FJ825377 & FJ825367 & & \\
\hline Pseudovirgaria grisea & CPC 19134 & JF957614 & & & \\
\hline $\begin{array}{l}\text { Pseudovirgaria } \\
\text { hyperparasitica }\end{array}$ & CPC 10753 & EU041824 & & & \\
\hline Psiloglonium araucanum & CMW 18760 & FJ161192 & FJ161151 & & \\
\hline Psiloglonium araucanum & CBS 112412 & FJ161172 & FJ161133 & FJ161089 & FJ161112 \\
\hline Psiloglonium araucanum & CMW 17941 & J161190 & FJ161149 & & \\
\hline $\begin{array}{l}\text { Psiloglonium } \\
\text { clavisporum }\end{array}$ & CBS 123340 & FJ161205 & & & \\
\hline $\begin{array}{l}\text { Psiloglonium } \\
\text { clavisporum }\end{array}$ & CBS 123341 & FJ161206 & & & \\
\hline $\begin{array}{l}\text { Psiloglonium } \\
\text { clavisporum }\end{array}$ & CBS 123338 & FJ161197k & & & \\
\hline $\begin{array}{l}\text { Psiloglonium } \\
\text { clavisporum }\end{array}$ & GKM L172A & GU323204 & GU323192 & & \\
\hline $\begin{array}{l}\text { Psiloglonium } \\
\text { clavisporum }\end{array}$ & GKM344A & GQ221889 & & & \\
\hline Psiloglonium colihuae & MFLUCC 110178 & KP744511 & & & \\
\hline $\begin{array}{l}\text { Psiloglonium } \\
\text { macrosporum }\end{array}$ & MFLUCC 130448 & KU243049 & & & \\
\hline $\begin{array}{l}\text { Psiloglonium } \\
\text { macrosporum }\end{array}$ & MFLU 16-0955 & MH535903 & & & \\
\hline $\begin{array}{l}\text { Psiloglonium } \\
\text { multiseptatum }\end{array}$ & MFLUCC 11 C0164 & KP744512 & & & \\
\hline Psiloglonium sasicola & MFLUCC 100565 & KP744513 & & & \\
\hline Psiloglonium simulans & CBS 20634 & FJ161178 & FJ161139 & FJ161094 & FJ161116 \\
\hline Psiloglonium simulans & ANM1557 & GQ221873 & & & \\
\hline $\begin{array}{l}\text { Quadricrura } \\
\text { septentrionalis }\end{array}$ & HC 4983 & AB524615 & AB524474 & AB524830 & \\
\hline Quasiconcha reticulata & EB QR & GU397349 & & & \\
\hline Rhexothecium globosum & CBS 95573 & HG004544 & & & \\
\hline $\begin{array}{l}\text { Rhytidhysteron } \\
\text { hysterinum }\end{array}$ & EB 0351 & GU397350 & & GU397340 & \\
\hline $\begin{array}{l}\text { Rhytidhysteron } \\
\text { neorufulum }\end{array}$ & MFLUCC 130221 & KU377567 & KU377572 & & \\
\hline $\begin{array}{l}\text { Rhytidhysteron } \\
\text { neorufulum }\end{array}$ & MFLUCC 130216 & KU377566 & KU377571 & KU510400 & \\
\hline Rhytidhysteron opuntiae & GKM1190 & GQ221892 & & & \\
\hline Rhytidhysteron rufulum & $361 \mathrm{~A}$ & GU301867 & GU296192 & & \\
\hline Rhytidhysteron rufulum & GKM361A & GQ221893 & & & \\
\hline Rhytidhysteron rufulum & MFLUCC 120529 & KJ526124 & KJ546127 & & \\
\hline Rhytidhysteron rufulum & HUEFS 192194 & KF914915 & & & \\
\hline Rhytidhysteron rufulum & MFLUCC 120528 & KJ418117 & KJ418119 & & \\
\hline Rhytidhysteron rufulum & AFTOL ID 2109 & FJ469672 & & & \\
\hline Rhytidhysteron rufulum & MFLUCC 120011 & KJ418109 & KJ418110 & & \\
\hline Rhytidhysteron rufulum & MFLUCC 120567 & KJ526126 & KJ546129 & & \\
\hline
\end{tabular}


Appendix 1 Continued.

\begin{tabular}{|c|c|c|c|c|c|}
\hline Species name & Strain & LSU & SSU & TEF & RPB2 \\
\hline Rhytidhysteron rufulum & EB 0381 & GU397351 & GU397366 & & \\
\hline Rhytidhysteron rufulum & MFLUCC 140577 & KU377565 & KU377570 & KU510399 & \\
\hline Rhytidhysteron rufulum & EB 0384 & GU397354 & GU397368 & & \\
\hline Rhytidhysteron rufulum & EB 0382 & GU397352 & & & \\
\hline Rhytidhysteron rufulum & EB 0383 & GU397353 & GU397367 & & \\
\hline Rhytidhysteron rufulum & MFLUCC 120013 & KJ418111 & KJ418113 & & \\
\hline Rhytidhysteron rufulum & MFLUCC 120530 & KJ526125 & KJ546128 & & \\
\hline $\begin{array}{l}\text { Rhytidhysteron } \\
\text { thailandicum }\end{array}$ & MFLUCC 140503 & KU377564 & KU377569 & KU497490 & \\
\hline Roussoella hysterioides & KT 1651 & AB524621 & AB524480 & AB539114 & AB539101 \\
\hline Saccardoella rhizophorae & JK 5456A & GU479799 & GU479766 & GU479860 & \\
\hline $\begin{array}{l}\text { Schismatomma } \\
\text { decolorans }\end{array}$ & AFTOL-ID 307 & AY548815 & AY548809 & DQ883725 & DQ883715 \\
\hline Schizothyrium pomi & CBS 40661 & EF134949 & & & \\
\hline Setomelanomma holmii & CBS 110217 & GQ387633 & GQ387572 & GU349028 & GU371800 \\
\hline $\begin{array}{l}\text { Stigmatodiscus } \\
\text { enigmaticus }\end{array}$ & L83 & & KU234131 & & KU234126 \\
\hline Stigmatodiscus pruni & L167 & KX611110 & KX611110 & KX611111 & KX61110s \\
\hline Strigula jamesii & MPN548 & JN887404 & JN887388 & JN887432 & \\
\hline Strigula nemathora & MPN72 & JN887405 & JN887389 & JN887433 & \\
\hline Sympoventuria capensis & CPC 12840 & KF937238 & & & KF937272 \\
\hline $\begin{array}{l}\text { Teratosphaeria } \\
\text { jonkershoekensis }\end{array}$ & CBS 112224 & KF901827 & GU301874 & KF903090 & KF902183 \\
\hline Tetraplosphaeria sasicola & KT 563 & AB524631 & AB524490 & AB524838 & \\
\hline Thyridaria rubronotata & CBS 41985 & GU301875. & & GU349002 & GU371728 \\
\hline Trematosphaeria pertusa & CBS 122371 & GU301876 & FJ201993 & KF015702 & GU371801 \\
\hline $\begin{array}{l}\text { Trichodelitschia } \\
\text { bisporula }\end{array}$ & CBS 26269 & GU348996 & GU349000 & GU349020 & GU371802 \\
\hline Trichodelitschia munkii & Kruys 201 & DQ384096 & DQ384070 & & \\
\hline Tripospermum myrti & CBS 43768 & GU323216 & GU566744 & & GU561854 \\
\hline Trypethelium tropicum & MPN130 & KM453819 & & & \\
\hline Tubeufia paludosa & CBS 120503 & GU301877 & GU296203 & GU349024 & GU371731 \\
\hline Tyrannosorus pinicola & CBS 124.88 & DQ470974 & DQ471025 & DQ471098 & DQ470928 \\
\hline Ulospora bilgramii & AFTOL ID 1598 & DQ678076 & DQ678025 & DQ677921 & DQ677974 \\
\hline Valsaria insitiva & CBS 127882 & KP687886 & & KP688054 & KP687959 \\
\hline Valsaria lopadostomoides & CBS 139062 & KP687868 & KP687972 & KP688037 & KP687943 \\
\hline Valsaria neotropica & CBS 139064 & KP687874 & KP687974 & KP688042 & KP687948 \\
\hline Venturia inaequalis & CBS 81569 & GU301878 & GU296204 & GU349023 & \\
\hline Verruculina enalia & AFTOL ID 1601 & DQ678079 & DQ678028 & DQ677924 & DQ677977 \\
\hline Zeloasperisporium cliviae & CPC 25145 & KR476781 & & & \\
\hline $\begin{array}{l}\text { Zeloasperisporium } \\
\text { ficusicola }\end{array}$ & MFLUCC 150222 & KT387735 & KT387736 & & \\
\hline $\begin{array}{l}\text { Zeloasperisporium } \\
\text { wrightiae }\end{array}$ & MFLUCC 150210 & KT387739 & KT387743 & & \\
\hline
\end{tabular}

